LA-14017

Approved for public release;

distribution is unlimited.

\title{
A Wildfire Behavior Modeling System at Los Alamos National Laboratory for Operational Applications
}

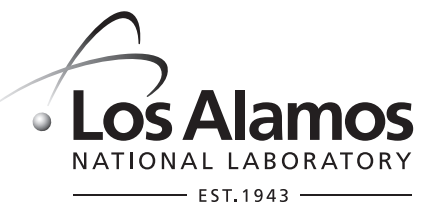

The World's Greatest Science Protecting America 
Edited by Hector Hinojosa, Group IM-1

Prepared by Teresa Hiteman, Group RRES-ECO

Los Alamos National Laboratory, an affirmative action/equal opportunity employer, is operated by the University of California for the United States Department of Energy under contract W-7405-ENG-36.

This report was prepared as an account of work sponsored by an agency of the United States Government. Neither the Regents of the University of California, the United States Government nor any agency thereof, nor any of their employees make any warranty, express or implied, or assume any legal liability or responsibility for the accuracy, completeness, or usefulness of any information, apparatus, product, or process disclosed, or represent that its use would not infringe privately owned rights. Reference herein to any specific commercial product, process, or service by trade name, trademark, manufacturer, or otherwise does not necessarily constitute or imply its endorsement, recommendation, or favoring by the Regents of the University of California, the United States Government, or any agency thereof. The views and opinions of authors expressed herein do not necessarily state or reflect those of the Regents of the University of California, the United States Government, or any agency thereof. Los Alamos National Laboratory strongly supports academic freedom and a researcher's right to publish; as an institution, however, the Laboratory does not endorse the viewpoint of a publication or guarantee its technical correctness. 
LA-14017

Issued: November 2004

\section{A Wildfire Behavior Modeling System \\ at Los Alamos National Laboratory \\ for Operational Applications}

Randy G. Balice

Steven W. Koch 



\section{Contents}

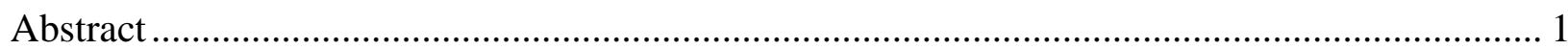

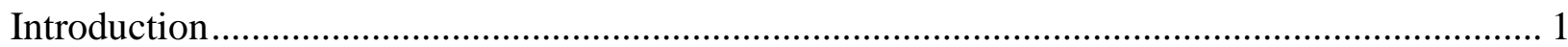

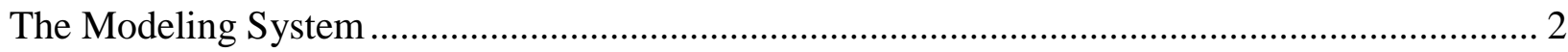

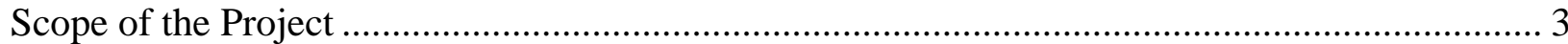

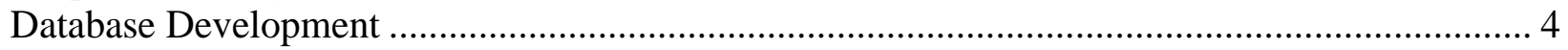

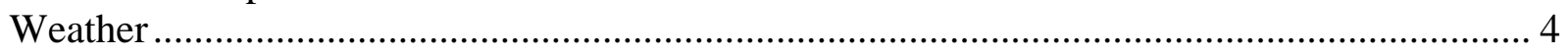

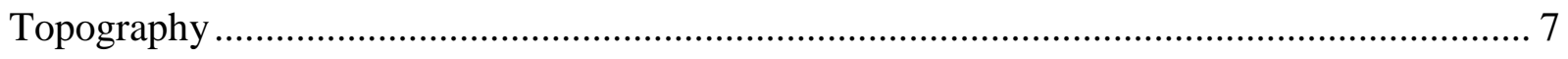

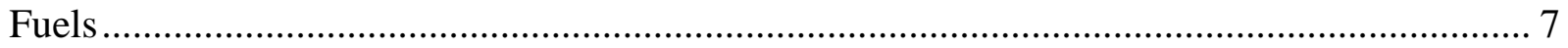

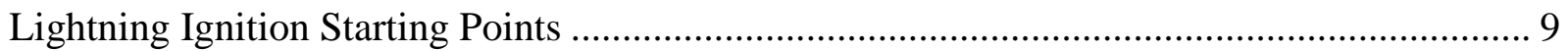

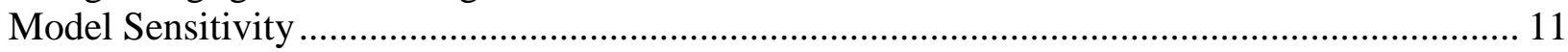

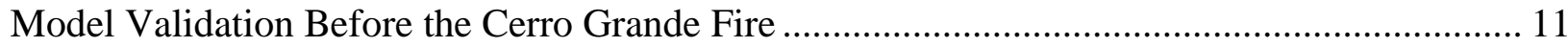

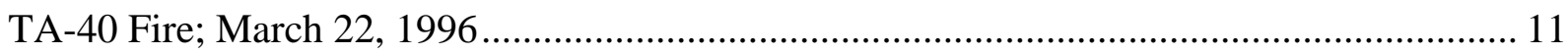

Model Validation After the Cerro Grande Fire....................................................................... 13

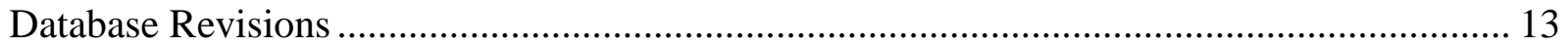

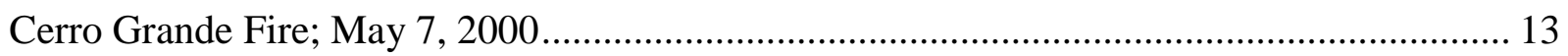

Cerro Grande Fire North; May 10, 2000 .......................................................................... 16

Cerro Grande Fire South; May 10, 2000 ....................................................................... 18

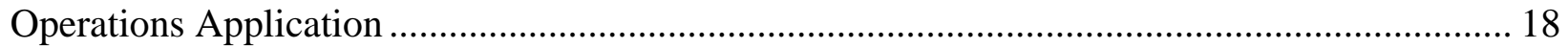

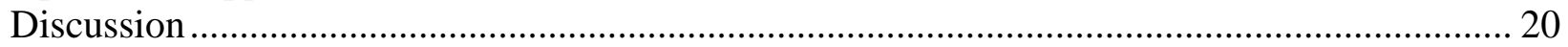

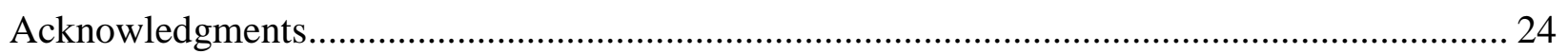

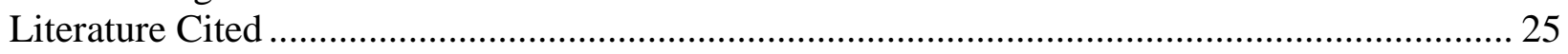

\section{Figures}

Figure 1. Design of the wildfire behavior modeling system. ……........................................... 3

Figure 2. The Los Alamos region of interest showing major roads and ownership boundaries.. 5

Figure 3. Locations of LANL weather monitoring sites. ........................................................... 6

Figure 4. Distribution of wildfire hazard monitoring plots; 1997 to 2001 .................................... 7

Figure 5. Locations and relative intensities of lightning strikes................................................. 10

Figure 6. Sensitivity of the FARSITE modeling system to varying levels of selected inputs... 12

Figure 7. Model results at two-hour intervals of the Sunday, May 7, segment of the Cerro Grande Fire using weather data from the (A) Pajarito Mountain, (B) TA-6, (C) TA-49, and (D) TA-54 weather towers................................................................... 14

Figure 8. Model results at two-hour intervals of the Wednesday, May 10, northern segment of the Cerro Grande Fire using weather data from Pajarito Mountain. ....................... 17

Figure 9. Model results at two-hour intervals of the Wednesday, May 10, southern segment of the Cerro Grande Fire using weather data from TA-49....................................... 19

Figure 10. Results of a simulated three-day wildfire, using conditions from 5/7/00 to 5/9/00... 21

Figure 11. Results of a simulated three-day wildfire, using conditions from 5/9/00 to 5/11/00. 21

Figure 12. Results of a simulated four-hour wildfire in the TA-36 and TA-54 areas of Los Alamos National Laboratory, using conditions from (A) 5/7/00 and (B) 5/10/00, .... 22 


\section{Tables}

Table 1. Weather towers in the Los Alamos region that provide readily accessible data of meteorological and climatological information.

Table 2. Results of the statistical tests to detect spatial patterns within the set of lightning strikes...... 


\title{
A Wildfire Behavior Modeling System at Los Alamos National Laboratory for Operational Applications
}

\author{
Randy G. Balice and Steven W. Koch
}

\begin{abstract}
To support efforts to protect facilities and property at Los Alamos National Laboratory from damages caused by wildfire, we completed a multiyear project to develop a system for modeling the behavior of wildfires in the Los Alamos region. This was accomplished by parameterizing the FARSITE wildfire behavior model with locally gathered data representing topography, fuels, and weather conditions from throughout the Los Alamos region. Detailed parameterization was made possible by an extensive monitoring network of permanent plots, weather towers, and other data collection facilities. We also incorporated a database of lightning strikes that can be used individually as repeatable ignition points or can be used as a group in Monte Carlo simulation exercises and in other randomization procedures. The assembled modeling system was subjected to sensitivity analyses and was validated against documented fires, including the Cerro Grande Fire. The resulting modeling system is a valuable tool for research and management. It also complements knowledge based on professional expertise and information gathered from other modeling technologies. However, the modeling system requires frequent updates of the input data layers to produce currently valid results, to adapt to changes in environmental conditions within the Los Alamos region, and to allow for the quick production of model outputs during emergency operations.
\end{abstract}

\section{Introduction}

Since the occurrence of the Dome Fire in 1996, Los Alamos National Laboratory (LANL) and its neighboring land managers have become increasingly interested in protecting their resources from potential damages caused by wildfires. This awareness was significantly heightened by the Cerro Grande Fire. During the first week of May 2000, the Cerro Grande Fire burned over 43,000 acres of Bandelier National Monument, Santa Fe National Forest, LANL, Los Alamos County, Valles Caldera National Preserve, Pueblo of San Ildefonso, and Pueblo of Santa Clara lands (Site-wide Issues Program Office 2000). With regard to the portion of the Cerro Grande Fire that occurred on LANL property, approximately 7500 acres were burned and 112 Laboratory structures were destroyed.

Even before the Cerro Grande Fire, LANL and the Department of Energy (DOE) had recognized the safety issues associated with wildfires and had given the reduction of wildfire hazards a high priority (DOE LAAO 2000). Subsequent to the Cerro Grande Fire, LANL completed a wildfire 
hazard reduction project plan that identifies and prioritizes planning areas and wildfire hazard reduction projects (Bare et al. 2001). This plan also recognizes field monitoring, to assess fuel loads and evaluate progress towards wildfire hazard reduction, as an important component in the planning process and implementation. Furthermore, the resulting site-specific databases have extensive application in the parameterization of "a fire behavior model that is used to predict fire intensities and growth" (Bare et al. 2001, page 20).

In 2003, DOE released Order 450.1 that establishes Environmental Management Programs at DOE installations and facilities (DOE 2003). This DOE Order also specifically notes that protection of resources from wildland and operational fires should be considered. DOE also issued its Wildland Fire Management Policy that adopted Federal Wildland Fire Management Policy and Implementing Actions at DOE sites (Abraham 2003). Federal policy and associated DOE guidance recommends that DOE facilities conduct fire management planning and monitoring on an interagency basis with stakeholder involvement. Wildfire behavior modeling systems are important components of fire management planning and monitoring (Webb and Balice 2004).

To support LANL's and DOE's requirements to protect facilities and property from damages caused by wildfire, we completed a three-year project to develop a system for modeling the behavior of wildfires in the Los Alamos region (Balice et al. 1998). This was done in conjunction with modeling of soil erosion potentials that can be affected by wildfires (Miller, Nyhan, and Yool 2003). Subsequent to the completion of the initial project to develop the modeling system, we continued to incorporate new data as they became available or as required by unexpected changes to environmental conditions. The current report describes the overall modeling system, outlines the development of the databases required by the components of the modeling system, and briefly discusses the sensitivity analyses and the validation exercises that were completed. This report concludes with some examples of operational applications of the wildfire behavior modeling system.

\section{The Modeling System}

LANL is well suited for this type of modeling activity because of the environmental diversity throughout LANL and the surrounding region (Balice, Ferran, and Foxx 1997; Balice 1998) and the presence of mature programs for monitoring weather (Baars, Holt, and Stone 1998), soils (Nyhan et al. 1978), and vegetation (Balice, Oswald, and Martin 1999; Balice et al. 2000a). In addition, LANL maintains a strong computing and geographic information system (GIS) support capability (Bennett et al. 2001). As part of the project described in this report, we were able to combine these attributes of LANL in an optimal fashion by adopting FARSITE (Version 3) and the Enhanced Universal Soil Loss Equation (USLE) for modeling wildfire behavior and soil erosion, respectively. In all cases, the specific input data were derived from existing, locally collected, monitoring data that had been converted to spatially explicit formats (Koch and Balice 1999, Balice et al. 2002a).

FARSITE is a model for spatially and temporally simulating the spread of wildfires over heterogeneous surfaces of terrain, fuels, and weather (Finney 1998). FARSITE uses previously 
established estimators of rate of spread, intensity, flame length, and other fire parameters (Rothermal 1983, Andrews 1986). These are projected in space and through time according to wave propagation principles. To produce these results, FARSITE requires three general classes of spatial inputs: weather, topography, and fuels (Figure 1). We combined these and other input data layers with a list of lightning strikes for initiating the model. The result is an interactive system to produce outputs of wildfire effects, such as total area burned, heat per unit area, rate of spread, and occurrence of crown fires. These outputs are used to assess potential effects on LANL facilities, regional vegetation, and soils. Soil erosion potentials are calculated with additional spatial data layers of rainfall, vegetation cover, and soil erodibility, using the USLE model (Wischmeier and Smith 1978, Nyhan and Lane 1986).

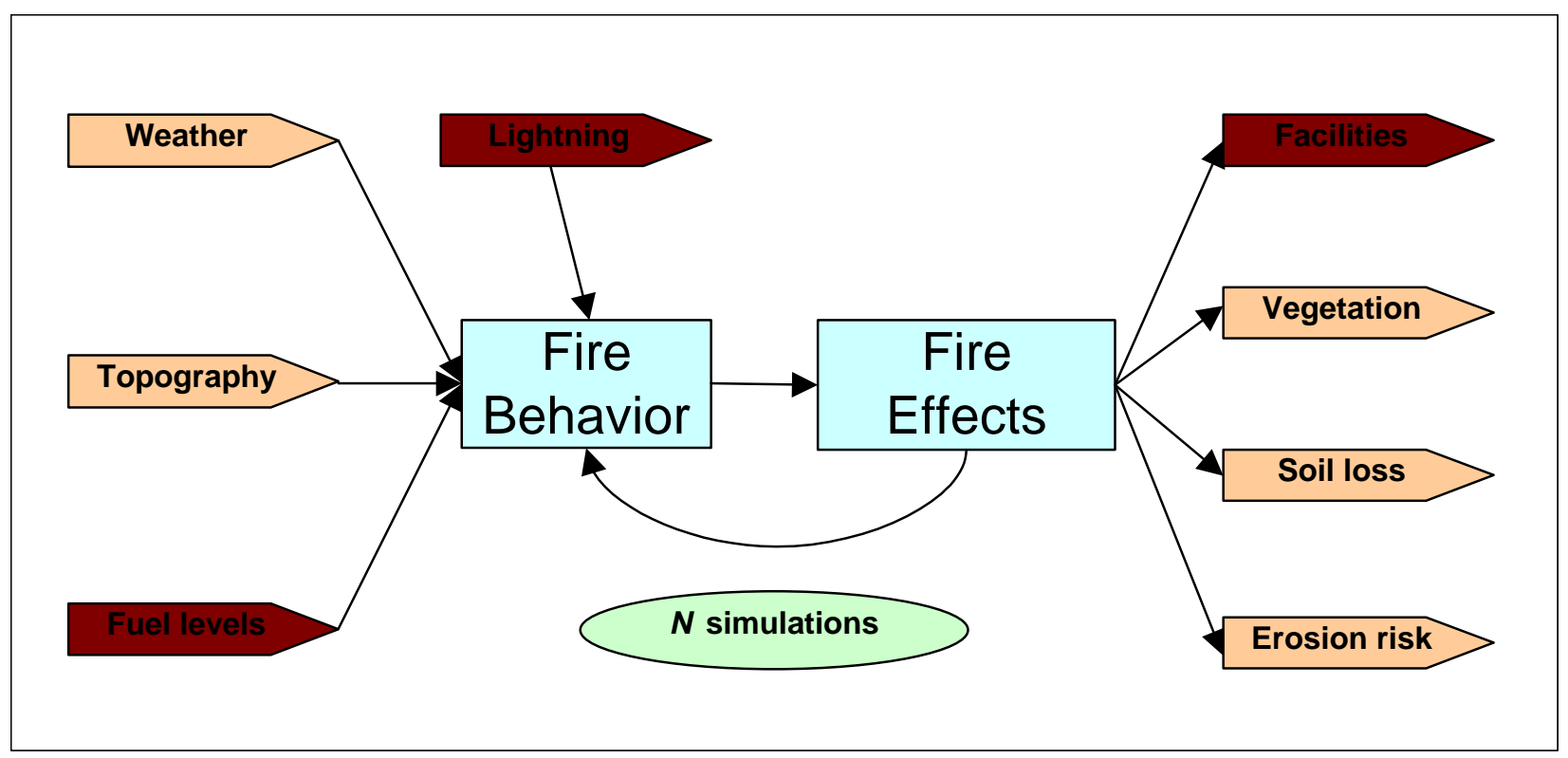

Figure 1. Design of the wildfire behavior modeling system.

The entire modeling system has the additional advantage that it can be used to perform Monte Carlo simulations of wildfire effects on facilities, vegetation, or soils (Figure 1). Although the modeling system can be initiated manually at any location within the boundaries of the database, we also adopted a database of lightning strikes for use as a source of repeated, randomized initiations to the wildfire behavior model. With these data of lightning strikes, the model can be run repeatedly under controlled conditions. This allows for the isolation and examination of a single factor of interest to scientific investigations or to management decision-making.

\section{Scope of the Project}

The objective of this project was to develop a modeling instrument that utilizes locally gathered monitoring data to provide objective estimates of the risks to LANL from wildfire (Balice et al. 1998). This was done over the course of three years in five phases or tasks: 1) database 
development, 2) model development and validation, 3) simulation of expected losses to LANL from wildfire, 4) experimental comparison of selected wildfire hazard reduction treatments, and 5) compilation of optimal mitigation action strategies. Much of phase one, assembly of databases for performing modeling tasks, was completed during the first year of the project (Balice et al. 2000b). During the second year, we completed the development of the modeling system and conducted sensitivity analyses and validation exercises (Balice et al. 2002b). The third year was devoted to updating the databases in the wake of the Cerro Grande Fire and performing Monte Carlo simulations of fires, before and after thinning treatments, and estimating the potential economic impacts of these simulated fires to LANL (Balice et al. 2002a, Webb and Balice 2004).

The purpose of this report is to present details of the database development for the wildfire behavior components of the modeling system. The results of the sensitivity analyses and validation exercises were reported elsewhere (Balice et al. 2000b, Koch et al. 2000), but are also summarized here, along with additional analyses, as they pertain to database development. The results of the Monte Carlo simulations and economic analyses were reported previously (Balice et al. 2002a, Webb and Balice 2004).

The region of interest includes all of the area where wildfires could potentially spread onto LANL. However, because of the lack of available data for some parameter types and in an attempt to provide a simple, test-case scenario during the initial phases of the project, we originally constrained the area of interest to a smaller portion of the LANL region (Figure 2).

However, the Cerro Grande Fire rendered the initial test region obsolete and we expanded the region of interest to include all of the area that had been burned by the fire, as well as much of the region surrounding LANL that supported residual fuels in burned and unburned areas. As before, the final boundary of the expanded region was partially determined by the availability of data for each of the model inputs.

\section{Database Development}

\section{Weather}

Weather data for selected time periods, including temperature, relative humidity, wind speed, and wind direction, are available for downloading from the LANL Weather Machine website (Air Quality Group 2001). LANL collects and records data, averaged over 15-minute periods, for a comprehensive suite of weather parameters at each of six weather-monitoring stations (Table 1). Summaries of these data are also available on a 24-hour basis. The weather stations are dispersed throughout the Los Alamos region, from lower elevations near White Rock to the top of Pajarito Mountain (Figure 3). Wind speed, wind direction, and air temperature data used in this report were recorded at 12 meters above ground for each of the towers, except for the Pajarito Mountain tower. At the Pajarito Mountain tower, these data were recorded at 36 meters above ground level. Relative humidity was recorded at 1.2 meters above ground level, except at the Pajarito Mountain location, which measured and recorded relative humidity at 2.5 meters above the ground. 


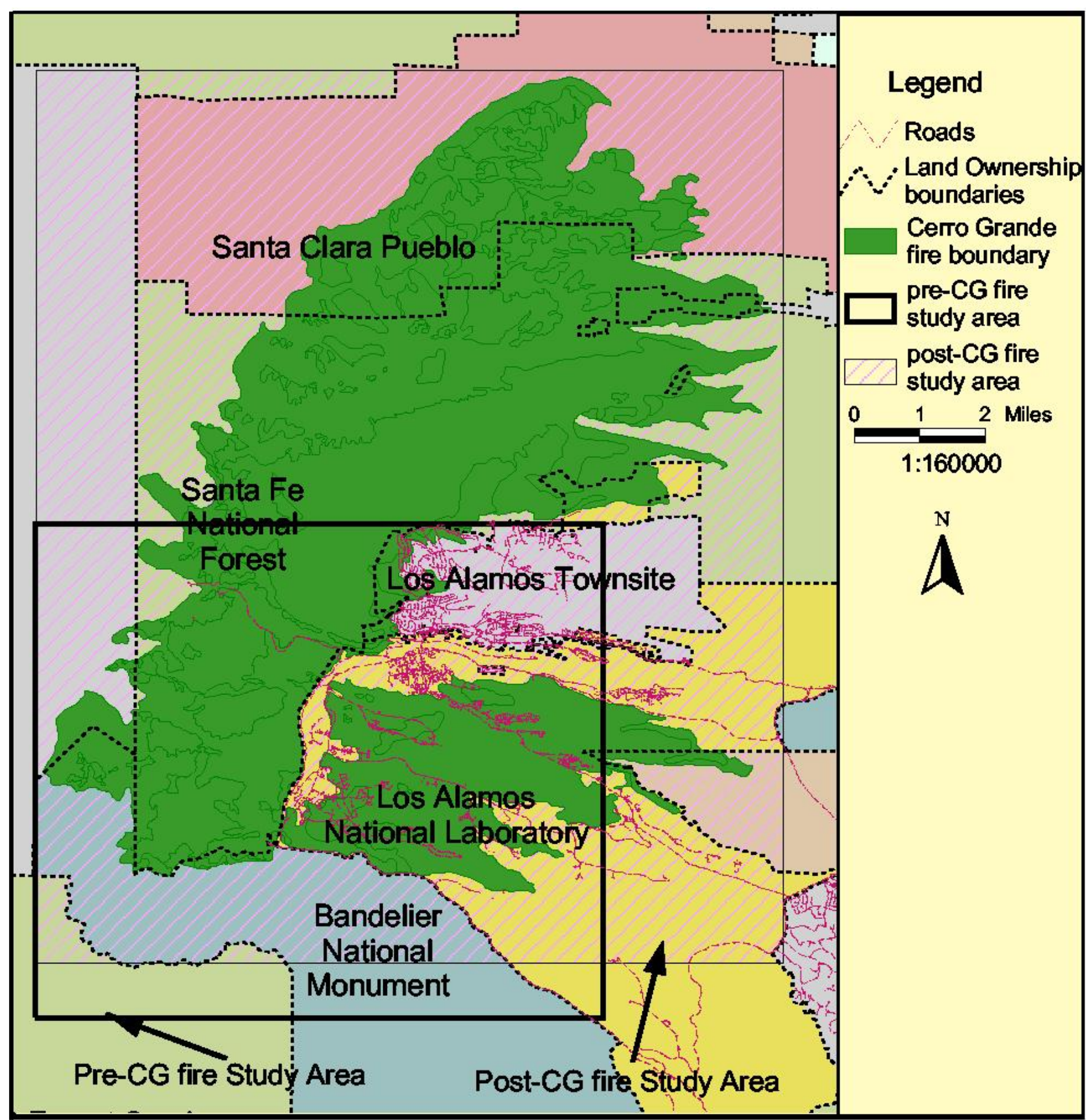

Figure 2. The Los Alamos region of interest showing major roads and ownership boundaries. The extent of the Cerro Grande Fire is shown in dark green. The initial study area that was defined before the Cerro Grande Fire (Pre-CG fire Study Area) and the expanded study area that was implemented after the Cerro Grande Fire (PostCG fire Study Area) are also shown. 
Table 1. Weather towers in the Los Alamos region that provide readily accessible data of meteorological and climatological information. Based on data provided by the Air Quality Group, LANL. (Note: TA indicates Technical Area.)

\begin{tabular}{|c|c|c|c|c|}
\hline Tower & Longitude & Latitude & Elevation (m) & Elevation (ft) \\
\hline TA-54 & $106^{\circ} 13^{\prime} 22.1^{\prime \prime}$ & $35^{\circ} 49^{\prime} 32.8^{\prime \prime}$ & 1996.3 & 6548 \\
\hline TA-41 & $106^{\circ} 17^{\prime} 45.1^{\prime \prime}$ & $35^{\circ} 52^{\prime} 35.0^{\prime \prime}$ & 2107.9 & 6914 \\
\hline TA-53 & $106^{\circ} 15^{\prime} 13.4^{\prime \prime}$ & $35^{\circ} 52^{\prime} 12.4^{\prime \prime}$ & 2131.1 & 6990 \\
\hline TA-49 & $106^{\circ} 17^{\prime} 55.5^{\prime \prime}$ & $35^{\circ} 48^{\prime} 47.8^{\prime \prime}$ & 2147.9 & 7045 \\
\hline TA-6 & $106^{\circ} 19^{\prime} 8.4^{\prime \prime}$ & $35^{\circ} 51^{\prime} 41.1^{\prime \prime}$ & 2263.4 & 7424 \\
\hline Pajarito Mountain & $106^{\circ} 23^{\prime} 43.5^{\prime \prime}$ & $35^{\circ} 53^{\prime} 11.2^{\prime \prime}$ & 3158.5 & 10,360 \\
\hline
\end{tabular}

\section{* Weather tower Boundary Paved road}

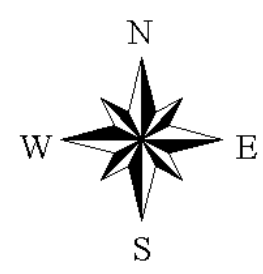

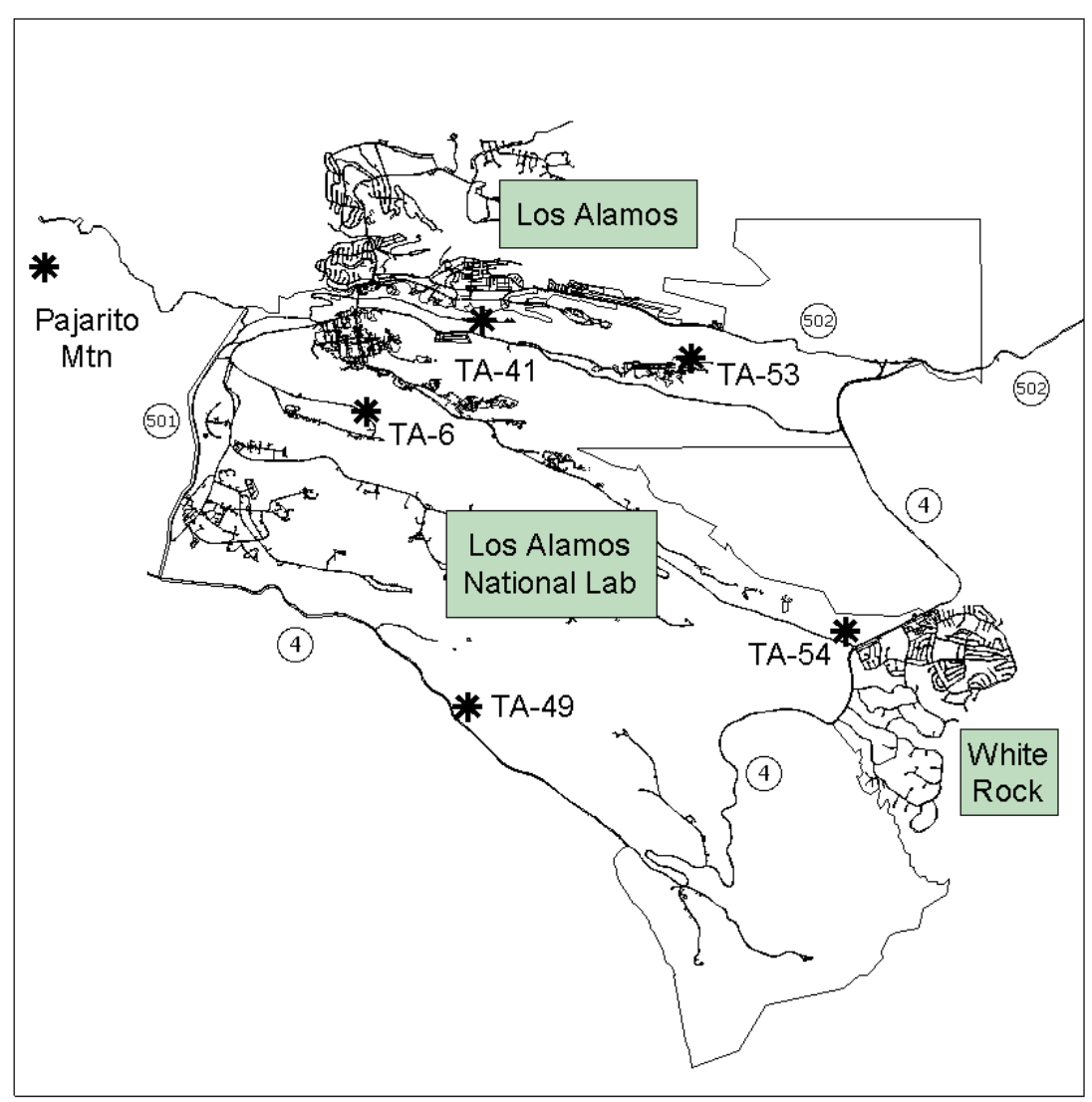

Figure 3. Locations of LANL weather monitoring sites. Based on information provided by the Air Quality Group, LANL. (Note: TA indicates Technical Area.)

To create data input files that are compatible with FARSITE, the downloaded weather data were incorporated into two files. One of these files, with weather data summarized over 24-hour periods, includes the maximum and minimum temperatures (degrees Centigrade) and relative humidities (percent), as well as the times for each day that these maximum and minimum values were recorded. The second input file, for one-hour periods, includes the wind speed (meters per second), wind direction (degrees from true north), and percent cloud cover. 


\section{Topography}

GIS data layers for topographic conditions were created for slope (percent), aspect (degrees from true north), and elevation (feet). These were produced from 1:24,000 digital elevation model (DEM) data (USGS 2001). Two representations of the DEM data were created, one at 10-meter resolution and one at 30-meter resolution. For all of the versions of the wildfire behavior modeling system discussed in this report, the 10-meter representation of the DEM was used.

\section{Fuels}

To create databases of fuels for use as inputs into the modeling system, we used data collected at permanent plots located throughout the Los Alamos region. These plots are components of a long-term monitoring program (Balice, Oswald, and Martin 1999; Balice et al. 2000a). The initial set of plots that was available to the database development process consisted of those that had been sampled from 1997 to 1999. As additional plot data became available during subsequent sampling years they were incorporated into the data layers, as needed and as funding was made available. The locations of these plots ranged from White Rock Canyon to the crest of the Sierra de los Valles (Figure 4). The respective numbers of sites sampled during each year are 54 in 1997, 29 in 1998, 47 in 1999, 115 in 2000, 51 in 2001, 56 in 2002, and 40 in 2003. All plots were sampled using quantitative methods, except during 1997 and 2000, when
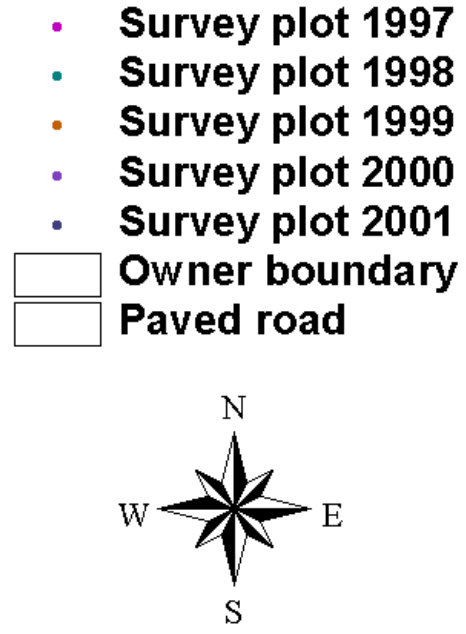

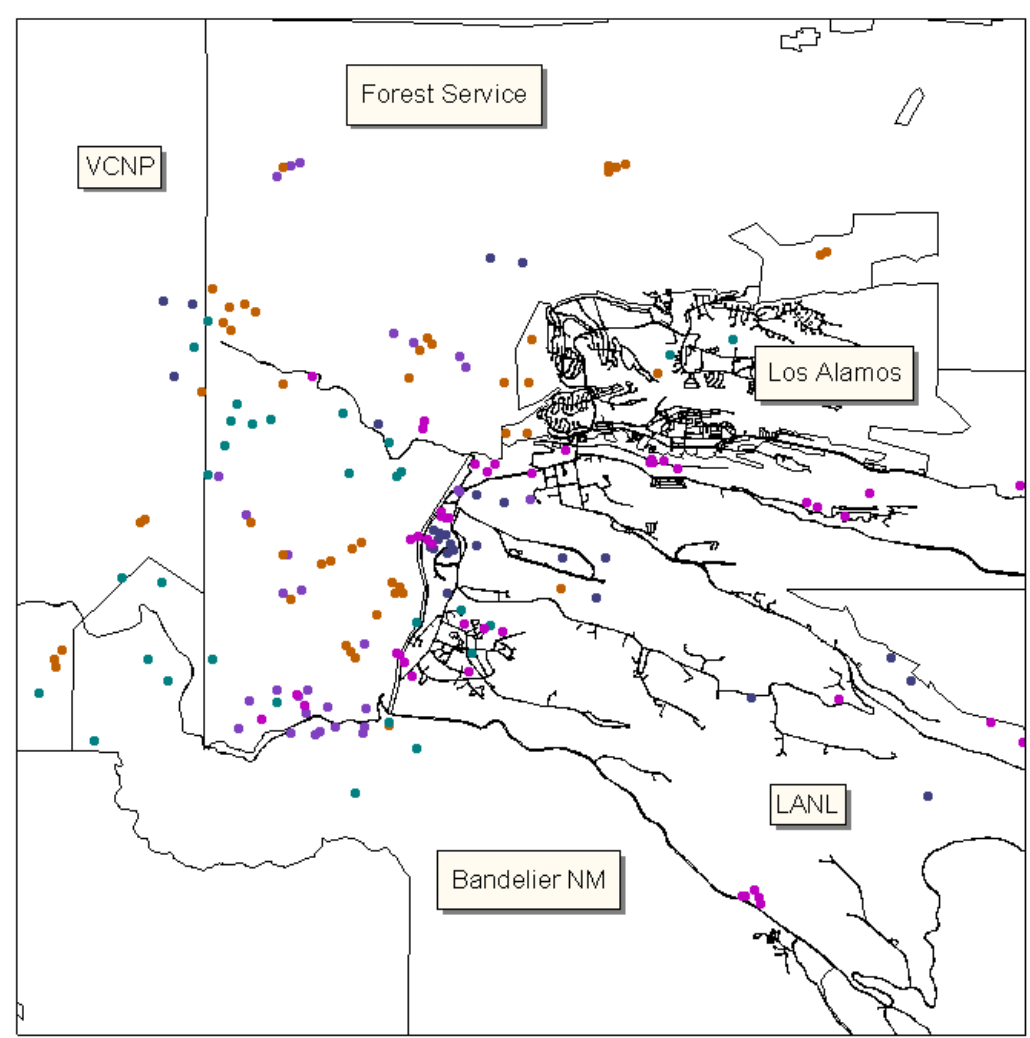

Figure 4. Distribution of wildfire hazard monitoring plots; 1997 to 2001. (Note: VCNP, LANL, and Bandelier NM indicate, respectively, Valles Caldera National Preserve, Los Alamos National Laboratory, and Bandelier National Monument.) 
reconnaissance methods were used. In addition, 13 plots in the piñon-juniper zone were sampled for tree mortality during the fall of 2002. Six of these plots were resampled for additional mortality during the fall of 2003.

For quantitatively sampled sites, the information collected at each plot can be categorized into descriptive and plot summary information, soil and surface fuel characteristics, shrub and sapling compositions, and overstory canopy structures. Descriptive information was collected for purposes of relocating the plot at a later date, for topographic characteristics, and for general vegetation conditions. Topographic characteristics of interest included the slope, aspect, elevation, topographic position, horizontal configuration, and vertical configuration of the subplot (Pfister et al. 1977). The slope was measured in percent and the aspect was measured in degrees from true north, assuming a declination of 10.5 degrees east. The topographic position was recorded as ridge, upper slope, mid slope, lower slope, bench or flat, or drainage bottom.

The horizontal and vertical configurations were listed as convex, concave, straight, or undulating. Finally, the topographic setting at the plots was recorded as canyon, mesa, or mountain.

The general vegetation conditions at each site were recorded in terms of dominant species, disturbance history, plant diseases, soil conditions, and other descriptive notes (Balice, Oswald, and Martin 1999, Balice et al. 2000a). The dominance type and habitat type or community type were also identified and listed. The dominance type was determined according to the dominant overstory species or, for nonforested vegetation, the physiognomic structure. For coniferous forests, the habitat type or plant community type, was recorded according to previous classifications by Balice, Ferran, and Foxx (1997); Balice (1998); or DeVelice et al. (1986). For aspen forests, community classifications developed in surrounding regions were used to determine the habitat type (Mueggler and Campbell 1986; Mueggler 1988; Komarkova, Alexander, and Johnston 1988).

At each plot, surface fuels, including 1-hour fuels, 10-hour fuels, 100-hour fuels, and 1000-hour fuels were also evaluated according to methods developed by Brown (1974) and Brown, Oberheu, and Johnston (1982). The fuel model was also recorded for each plot (Anderson 1982).

The data that had been collected at each permanent plot were summarized to parameters that can be used directly by the modeling software (Balice, Oswald, and Martin 1999, Balice et al. 2000a). In some cases, the fuel levels were calculated directly, whereas regression modeling was also used where required (Balice and Koch 2001). The total height (feet) of the vegetation was calculated as an average of the 10 tallest trees recorded in the plot. For purposes of this calculation, the tallest one or two trees were excluded from the calculation if it was more than 10 percent taller than the next tallest tree. The height from the ground to the live crown was averaged from measurements taken for every tree in the plot that was greater than 10 feet tall. Then, the measurement of the tallest shrub was subtracted from this average value to determine the distance (feet) between the ladder fuels and the overstory fuels. Percent canopy cover for each plot was averaged from 24 densiometer readings obtained at systematically determined points within the plot. 
Canopy bulk density data were not readily available for the forests of the southern Rocky Mountains. As a result, this information was originally adopted from Keane et al. (1998). However, allometric equations of individual-tree crown bulk density were subsequently adopted for piñon and one-seed juniper from Meeuwig (1979). Canopy bulk densities for forests consisting of most of the remaining tree species in the Los Alamos region, including ponderosa pine, Engelmann spruce, corkbark fir, Douglas fir, and ponderosa pine, can be estimated directly using a spreadsheet calculator provided by Reinhardt (2001).

Average values for each of these parameters described above were calculated by land cover type and were assigned to a previously developed land cover classification (Balice, Ferran, and Foxx 1997; Balice 1998) that had been incorporated into a land cover map (Koch, Budge, and Balice 1997). Certain land cover types, such as spruce-fir and shrub communities, did not have a representative class in the current version of the land cover map. To correct for this, we replaced the original names of related cover types with spruce-fir or shrub, as determined by topographic criteria. In areas that did not support vegetation, such as areas with bare rock or with buildings, facilities, and paved areas of more than one acre in size, the fuel model was set to unburnable. Finally, the FARSITE fuel adjustments for all fuel models were set to one in the Inputs/Fuel Files/Adjustments menu.

\section{Lightning Ignition Starting Points}

In order to develop a realistic database of fire starting points within the Los Alamos region, we adopted a dataset of lightning strike locations (Jacobson et al. 2000, Smith et al. 2002). These strike locations were organized by geographic coordinates and by signal strength (Figure 5). The time period for these data included April 1, 1998, to October 1, 1998. To limit the data set to lightning strikes that would occur during the wildfire season and would have sufficient energy to start a fire, we deleted all lightning strikes after July 11, as well as those with strengths less than 100 kiloamps. The resulting final dataset included 131 lightning strikes, and these were converted to Arc View shape files. For display purposes, the lightning strike locations were categorized into those with "weak" (100 to 112 kiloamps), "moderate" (112 to 126 kiloamps), and "strong" (>123 kiloamps) intensities (Figure 5).

If the lightning strikes are distributed across the study region in a random pattern, they can be used to initiate wildfires as part of Monte Carlo simulation exercises. To examine the assumption of randomness, we conducted statistical tests to determine if the pattern is uniform, random, or clustered (Davis 1973). The test uses a grid overlay and a $t$-statistic to compare the ratio of the mean number of lightning strikes per grid cell and the associated sample variance to unity. When the ratio of the mean to the sample variance is about equal to 1 , the pattern is random. When the ratio is significantly greater than one, which indicates that the mean is greater than the variance, the pattern is considered to be uniform. Conversely, when the ratio is significantly less than one, indicating that the mean is less than the variance, the pattern is clustered. For large numbers of cells in the grid, between 120 and 180, the critical level for the absolute value of $t$ is approximately 1.98 .

Since the number of grid cells may potentially affect the behavior of the $t$-statistic, we repeated the analysis using four different grid sizes. Two of these analyses, with 143 and 180 grid cells, were calculated from hand-drawn grids. The other two analyses, with 132 and 168 grid cells, were calculated from grids created by ArcGIS 8.3 (ESRI 2003). 


\section{Lightning strikes \\ - Strong \\ - Moderate \\ - Weak

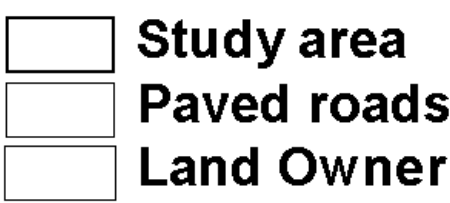

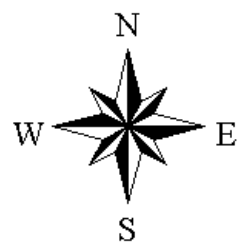

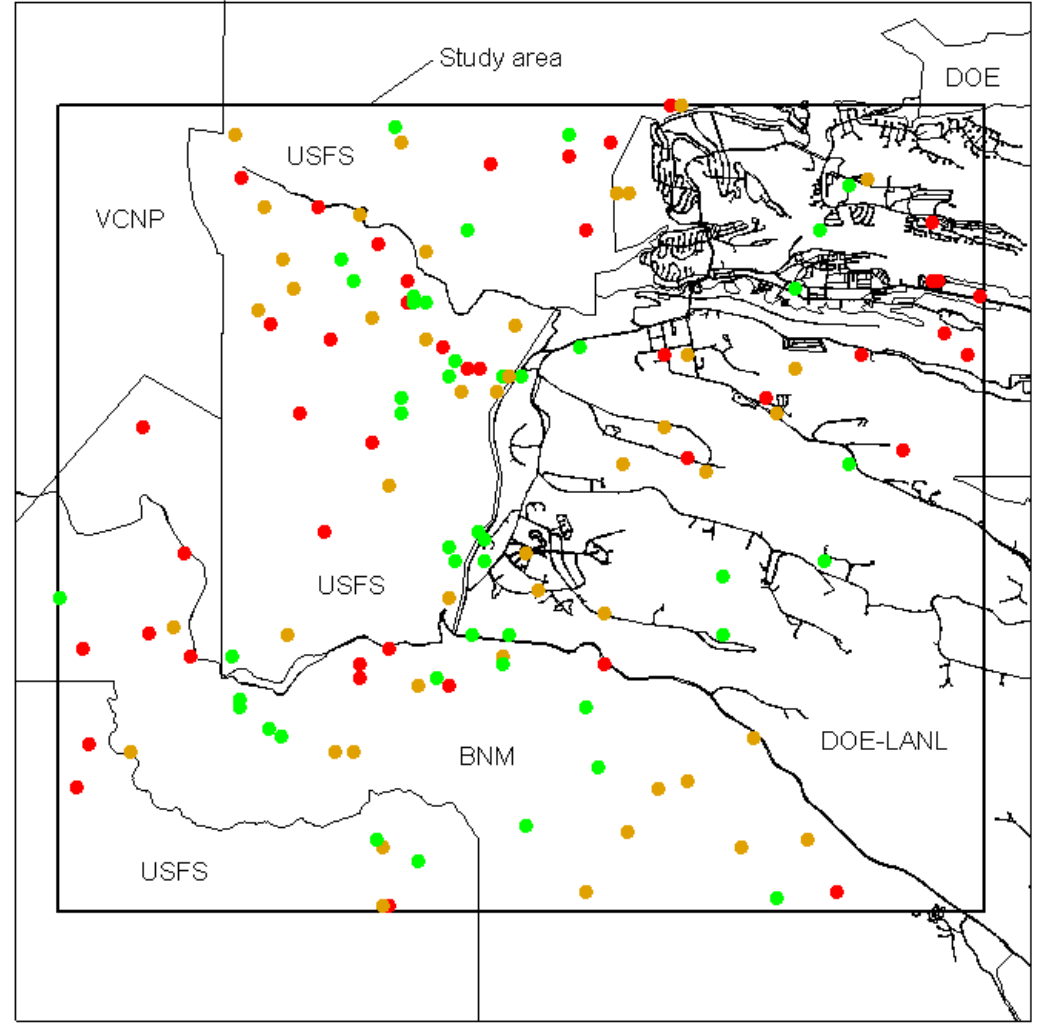

Figure 5. Locations and relative intensities of lightning strikes. (Note: VCNP, USFS, BNM, DOE-LANL, and DOE indicate, respectively, Valles Caldera National Preserve, US Forest Service, Bandelier National Monument, Los Alamos National Laboratory, and Department of Energy lands in Rendija Canyon.)

The results of these four statistical tests to detect spatial patterning within the set of lightning strikes are presented in Table 2 . In all cases, a significantly clustered pattern was detected. However, a systematic removal of lightning strikes from combinations of cells with the highest density, as indicated in Table 2, resulted in the reduction of the $t$-statistic to non-significant levels. Although the $t$-statistic varies with the number of grid cells, there appears to be no functional dependency between them.

The results of these analyses suggest that the set of lightning strikes is useful for two purposes. The original set that displays a clustered pattern may be used to represent the actual occurrence of lightning strikes that resulted during one fire season, that of 1998. In this example from 1998, clustering of lightning strikes occurs in the Pajarito Ridge area between State Highway 501 and Pajarito Mountain and also in the vicinity of the southwestern portion of LANL near the intersection between State Highway 4 and State Highway 501. In contrast, with the removal of selected strikes from the most clustered regions within the data set, the remaining set of lightning strikes may also be used as randomized starts to initiate wildfires for Monte Carlo simulations and for other randomized tests. 
Table 2. Results of the statistical tests to detect spatial patterns within the set of lightning strikes. For these conditions, the significance at the 0.05 probability level is indicated if the absolute value of the $t$-statistic exceeds 1.98 . With the removal of the indicated number of lightning strikes in the most clustered cells, the respective $t$-statistics are reduced to levels that are not statistically significant (less than 0.05 ).

\begin{tabular}{|c|c|c|c|c|c|c|}
\hline $\begin{array}{c}\text { Number of } \\
\text { cells }\end{array}$ & $\begin{array}{c}\text { Mean strikes } \\
\text { per cell }\end{array}$ & Variance & $\begin{array}{c}\text { Ratio: Mean } \\
\text { to variance }\end{array}$ & t-statistic & $\begin{array}{c}\text { Number } \\
\text { removed }\end{array}$ & $\begin{array}{c}\text { Adjusted } \\
\text { t-statistic }\end{array}$ \\
\hline 132 & 0.992 & 2.053 & 0.483 & -4.182 & 11 & -1.871 \\
\hline 143 & 0.916 & 1.331 & 0.688 & -2.626 & 3 & -1.792 \\
\hline 168 & 0.780 & 1.107 & 0.704 & -2.701 & 3 & -1.893 \\
\hline 180 & 0.728 & 1.182 & 0.615 & -3.638 & 8 & -1.895 \\
\hline
\end{tabular}

\section{Model Sensitivity}

The sensitivity of the wildfire behavior modeling system to changes in selected model parameter settings was examined, in otherwise homogeneous conditions (Balice et al. 2002b, Koch et al. 2000). The wind speed (8, 16, and 24 miles per hour), the distance between the ground and the base of the live fuel canopies ( 0.1 to 1.1 meters), and the fuel model $(1,2,9$, and 10$)$ were varied as part of this analysis. Fuel model 1 consists of short grass fuels, whereas fuel model 2 is timber with grass and herbaceous understory fuels, fuel model 9 is pine litter, and fuel model 10 is timber with herbaceous and woody surface fuels (Anderson 1982). Other parameters, including slope (0 percent), canopy cover ( 80 percent), crown bulk density $(0.26$ kilograms per cubic meter), and canopy height (20 meters), were held constant. Heat per unit area (kilojoules per square meter) was set as the dependent variable.

The result of the sensitivity analysis shows an interaction between the wind speed, the crown base heights, and the fuel model (Figure 6). As the wind speed increases and with increased amounts of grass and shrubs in the fuels, the fire intensity increases. Moreover, shrubby fuel beds that are within 1.0 meter of the overlying tree crowns will escalate more readily to crown fires than communities with greater separations between the ground fuels and the crown fuels. These results emphasize the importance of wind and fuel structures to development of wildfire databases, wildfire modeling, and management of wildfires. Moreover, these results indicate that interactions between these and other parameters are important to the behaviors of wildfires.

\section{Model Validation Before the Cerro Grande Fire}

\section{TA-40 Fire; March 22, 1996}

The wildfire behavior modeling system was partially validated against a wildfire that burned in Technical Area (TA) 40 for more than eight hours on March 22, 1996 (Balice et al. 2000b, Koch et al. 2000). Extensive suppression measures were exercised during this fire. Therefore, direct comparisons between the modeling results and observed field results are difficult to make. However, the modeled fire and the actual fire appeared to compare reasonably well. The shape of the modeled fire was more elliptic than the shape of the actual fire, which was rectangular. As 


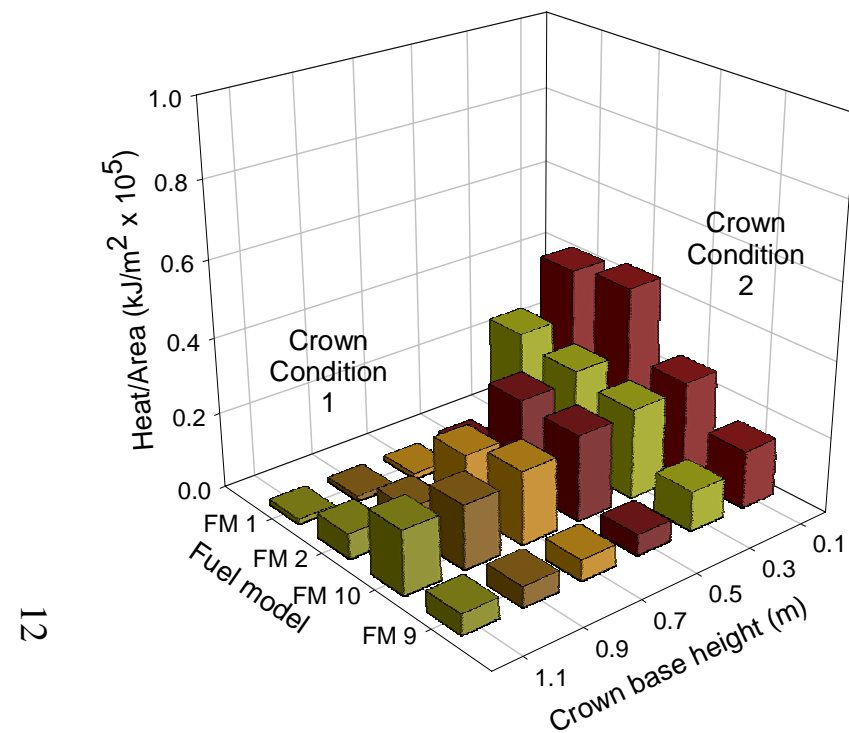

(a)

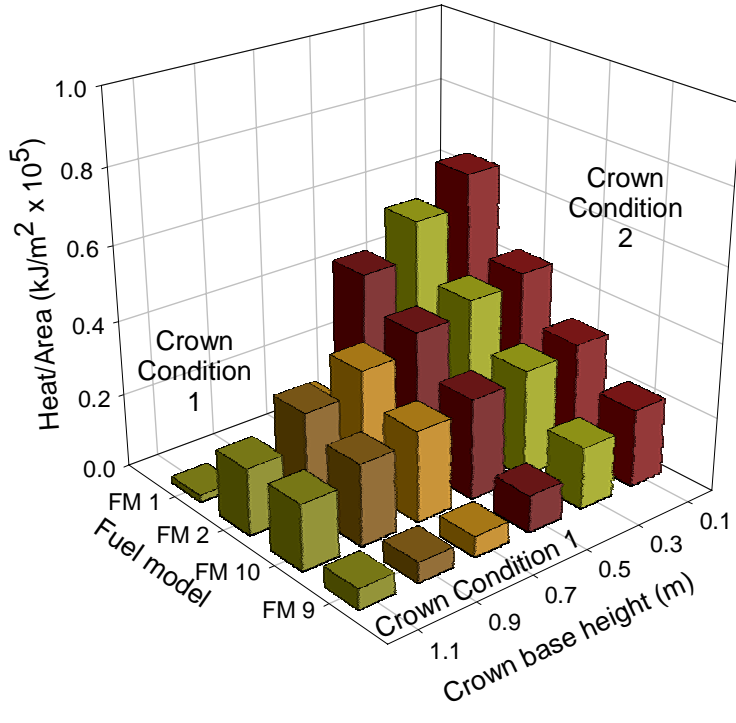

(b)

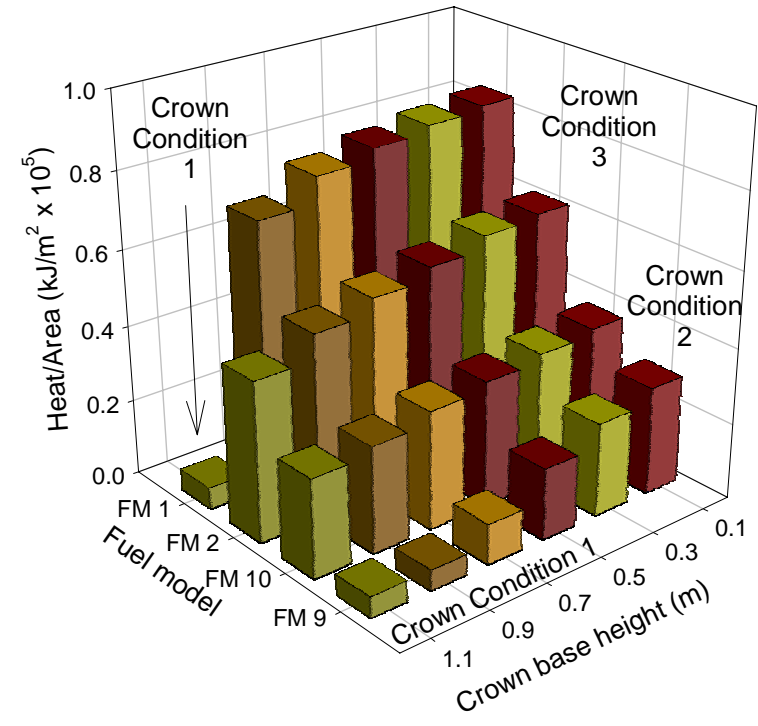

(c)

Figure 6. Sensitivity of the FARSITE modeling system to varying levels of selected inputs. The output variable is heat per unit area $\left(\mathrm{kJ} / \mathrm{m}^{2} \times 10^{5}\right)$. The input variables are fuel model (categorical); crown base height (meters); and (a) wind speed $=8$ miles per hour, (b) wind speed $=16$ miles per hour, and (c) wind speed $=24$ miles per hour. The expected fire behaviors with respect to crown conditions $(1=$ ground fire, $2=$ intermittent crown fire, and $3=$ continuous crown fire $)$ are also shown. Reproduced from Balice et al. (2002b). 
a result of the lessons learned from this validation exercise, recently available locally derived fuel model information and height-to-live-crown data were incorporated into the fire behavior modeling system (Balice et al. 2000b). These modifications and additions resulted in improvements to simulations of the TA-40 fire and emphasized the importance of using locally relevant fuels data for inputs to the modeling system.

\section{Model Validation After the Cerro Grande Fire}

\section{Database Revisions}

The Cerro Grande Fire had profound effects on the fuel structures in the Los Alamos region and it was desirable to revise and update the input data layers for the modeling system to reflect these changes. These revisions would allow for comparisons of fire behaviors and soil erosion potentials before and after the Cerro Grande Fire and would accommodate the need to address the residual fire hazards that exist after the fire. As a result, and in an effort to provide preliminary revisions to the fuels data layers, we modified the databases in the months following the Cerro Grande Fire. This focused on the primary first-order impacts of the fire, which were to the vegetation cover. First, we adopted the Burned Area Evaluation and Rehabilitation (BAER) Team burn severity maps that classified burn severities into high, moderate, low, and unburned (BAER Team 2000). Second, we incorporated data collected in the field during the summer of 2000. From preliminary analyses of these field data, it was learned that areas with high-burn severity contained virtually no fuels during the first summer after the fire. In contrast, the fuel levels of areas with moderate-burn severities or low-burn severities were somewhat similar to pre-Cerro Grande Fire conditions. As a result of these field observations, we set the areas that were burned at high severity during the Cerro Grande Fire to unburnable. In contrast, fuel levels of areas that were burned with low or moderate severities were left unchanged from pre-fire conditions.

Updated weather files were also created to reflect the weather conditions that were experience during the time period of the Cerro Grande Fire. For this purpose, weather data for the time period from May 1 to May 15, 2000, were downloaded from several LANL weather towers, including Pajarito Mountain, TA-6, TA-41, TA-49, and TA-54. In addition, fuel moisture data that were collected by Bandelier National Monument and by the US Forest Service during the time period during and immediately before the Cerro Grande Fire were also incorporated into the modeling system.

\section{Cerro Grande Fire; May 7, 2000}

With the updated weather and fuels information that was consistent with the Cerro Grande Fire, the Sunday, May 7, segment of this fire was selected for further modeling and for validation of the system. On May 7, 2000, the Cerro Grande Fire was burning in the Frijoles drainage above State Highway 4, as it had been on the previous day, May 6 (Figure 7). However, high winds promoted the advancement of the fire from the upper Frijoles Canyon area to the eastern side of the Sierra de los Valles in the upper Water Canyon area. The new fire was initiated by burning embers that transported into the forests in the upper Water Canyon. After burning in one place for several hours, the flames of this new fire entered the upper canopy of the forest and advanced 

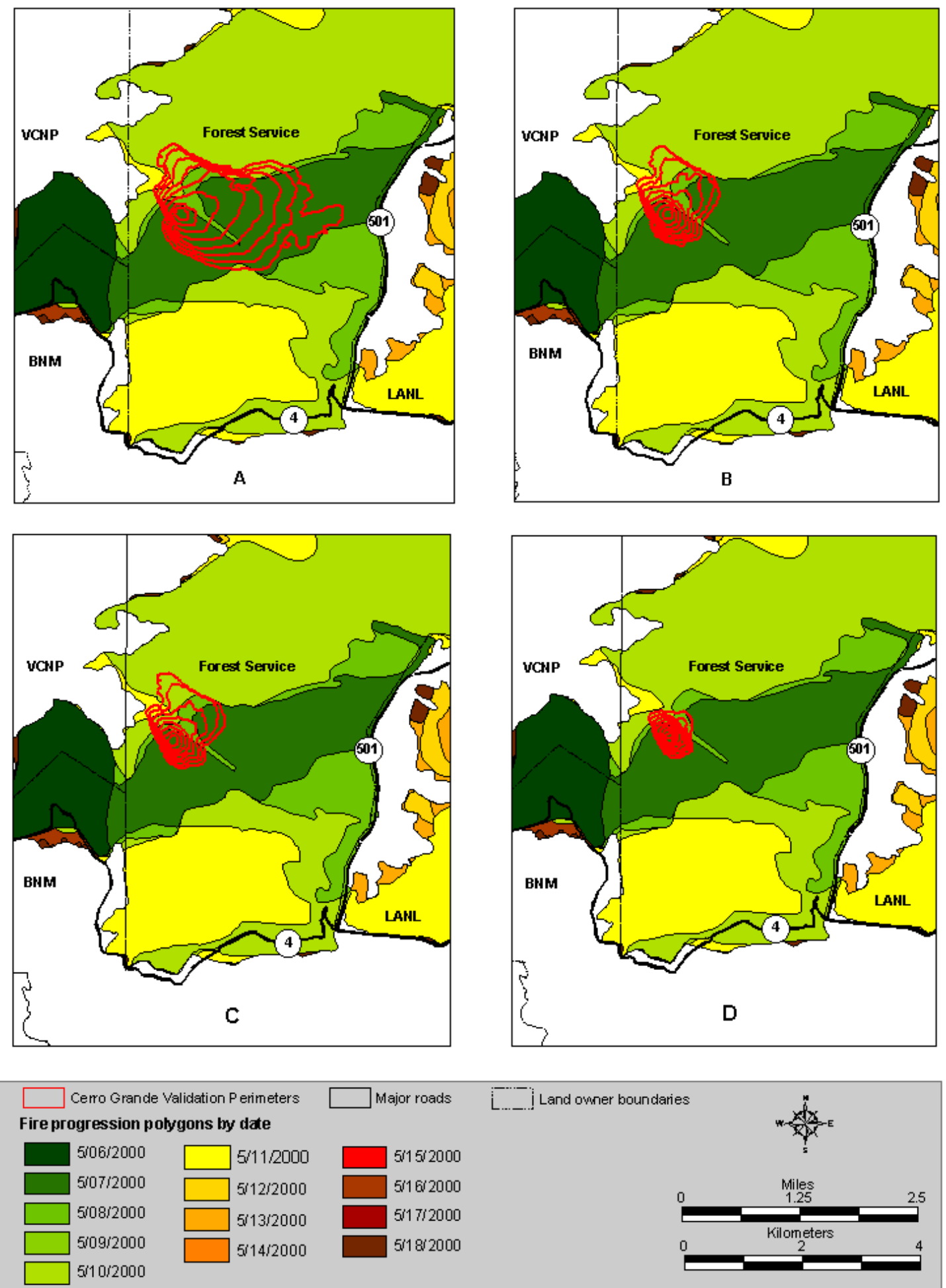

Figure 7. Model results at two-hour intervals of the Sunday, May 7, segment of the Cerro Grande Fire using weather data from the (A) Pajarito Mountain, (B) TA-6, (C) TA-49, and (D) TA-54 weather towers. (Note: VCNP, BNM, and LANL indicate Valles Caldera National Preserve, Bandelier National Monument, and Los Alamos National Laboratory, respectively.) 
to the northeast. By the end of the day, the fire had advanced nearly to the Ski Hill Road and Los Alamos Canyon. The fire did not cross State Highway 501 or the Ski Hill Road. However, burnouts were initiated at dusk along these two roads in an attempt to contain the fire from the northeast side. To the west, the area between the Frijoles drainage and the upper Water Canyon was also burned as the fire from the west side of the Sierra continued to burn eastward until it met with the original ignition location.

For validation purposes, this segment of the Cerro Grande Fire was modeled under constant conditions, including a constant GIS location for the starting point of the fire. In addition, to examine the sensitivity of the modeling system to different sources of weather data, we modeled the progression of the fire using weather data from four different weather towers. These include the towers at Pajarito Mountain, TA-6, TA-49, and TA-54. The progressions and perimeters of the Cerro Grande Fire that were validated against were adopted from the BAER Team fire progression map (BAER Team 2000). The time periods for these simulations were from 9 AM to midnight of the same day.

From these validation tests, the Pajarito Tower weather data modeled the Sunday, May 7 , segment of the Cerro Grande Fire with high fidelity (Figure 7A). Although the modeled fire perimeters in Figure 7A are somewhat conservative, consideration of the burnout operations to the northeast and the independent burning of the advancing flaming front from upper Frijoles Canyon to the west suggests that this conservatism is not more than 20 percent.

In contrast to the relatively accurate results provided by the use of the weather data from Pajarito Mountain, weather data from the TA-6 weather tower (Figure 7B), TA-49 weather tower (Figure 7C), and TA-54 weather tower (Figure 7D) modeled the Sunday segment with increasingly less fidelity. It is interesting to note that the Pajarito weather tower was the closest of the four weather towers to the starting point of the fire, both in terms of distance and elevation. The distance between the Pajarito tower and the fire starting point is less than two miles. The starting point for the fire was approximately 9000 feet, which is a difference of approximately 1400 feet compared to the Pajarito Mountain weather tower. In contrast, the TA-6, TA-49, and TA-54 weather towers are approximately three miles, five miles, and seven miles from the starting point for the fire, respectively. With regard to elevation differences, these three weather towers are approximately 1600 feet, 2000 feet, and 2500 feet lower, respectively, than the actual starting point of the fire.

The results of this analysis emphasize the importance of using accurate, locally gathered weather data, if the successful modeling of operational fires is desired. In this example, the substitution of weather data from sources with greater geographic separation from the true starting point, even those that were not more than three miles from the starting point, produced much less desirable results in our test case. This presents an interesting problem since weather data used to model the progress of operational fires are most frequently gathered from distant weather stations or at a time period previous to the actual burning of these operational fires. This is done because of availability of data or to save time when model outputs are needed quickly to provide useful input to managers of quickly advancing fires. However, given that the fuels and topography databases are accurate and relevant, the fidelity of the model outputs with regard to an operational fire will largely depend on the comparability of these weather input databases to the actual weather experienced by the fire. 


\section{Cerro Grande Fire North; May 10, 2000}

The segment of the Cerro Grande Fire that burned on the northern portions of the Los Alamos region and into the Los Alamos town site on Wednesday, May 10, 2000, was also useful for validating this fire behavior modeling system. On Tuesday, May 9, the Cerro Grande Fire had been burning for two days to the south of Los Alamos Canyon and along the lower elevations of the Ski Hill Road (Figure 8). This is a result of the advances of the fire that had been made on May 7. However, on the morning of May 10 strong winds carried burning embers across Los Alamos Canyon and these embers initiated new fires in at least two places to the north of the canyon. The fire quickly burned into the tree crowns and by late afternoon had advanced into the western area of Los Alamos, in the area of upper Trinity and Orange Streets, and in the northern area of the town site, along $48^{\text {th }}$ Street and Arizona Avenue. The fire continued to burn from house to house in these sections of the town site, as well as in forested regions to the north and northeast of Los Alamos, until late that evening.

Since the exact locations of the initiating fire starts on May 10 are unknown, several model runs of this fire were completed, each with two candidate start locations, to investigate the impact of varying these starting points. For each run, weather data for May 10 from the Pajarito Mountain weather tower were used. The polygons of the fire perimeters representing the actual progress of the Cerro Grande Fire were adopted from the BAER Team fire progression map (BAER Team 2000).

Selected results from this collection of model runs are shown in Figure 8. In each of the selected runs, the modeled fire successfully burned into the portions of the Los Alamos town site that were affected by the actual Cerro Grande Fire. However, modeled behaviors of the fire were more variable to the north of the town site where the Cerro Grande Fire continued to burn into forested landscapes and to the south of the town site where the Cerro Grande Fire did not burn into Los Alamos Canyon. Two of the modeled fires simulated the northern and southern extents of the Cerro Grande Fire with reasonable fidelity (Figures 8A and 8B). Although the portion of the actual fire that burned to the north of Los Alamos is modeled with some conservatism, the model results clearly mimic the direction and the general spread of the actual fire. To the south, similar results are achieved in Figures 8A and 8B, although the modeled fires did erroneously enter into Los Alamos Canyon in both cases. In contrast, the examples shown in Figures $8 \mathrm{C}$ and 8D did not faithfully model the actual Cerro Grande Fire as it burned to the north and to the south of Los Alamos town site. To the north, the extent of the actual fire was underestimated. To the south, the model outputs extend well into Los Alamos Canyon where the actual fire did not burn (Figures 8C and 8D).

This validation exercise emphasized the importance of using accurate location information to initiate the modeled fire. As shown in Figure 8, slight alterations of the ignition points can have relatively large effects on the locations and extents of the final perimeters of the modeled fire. This is true even for modeled fires that only burn for a single day, as in the case of the fire outputs shown in Figure 8 that burned for 15 hours, from 9 AM to midnight. 

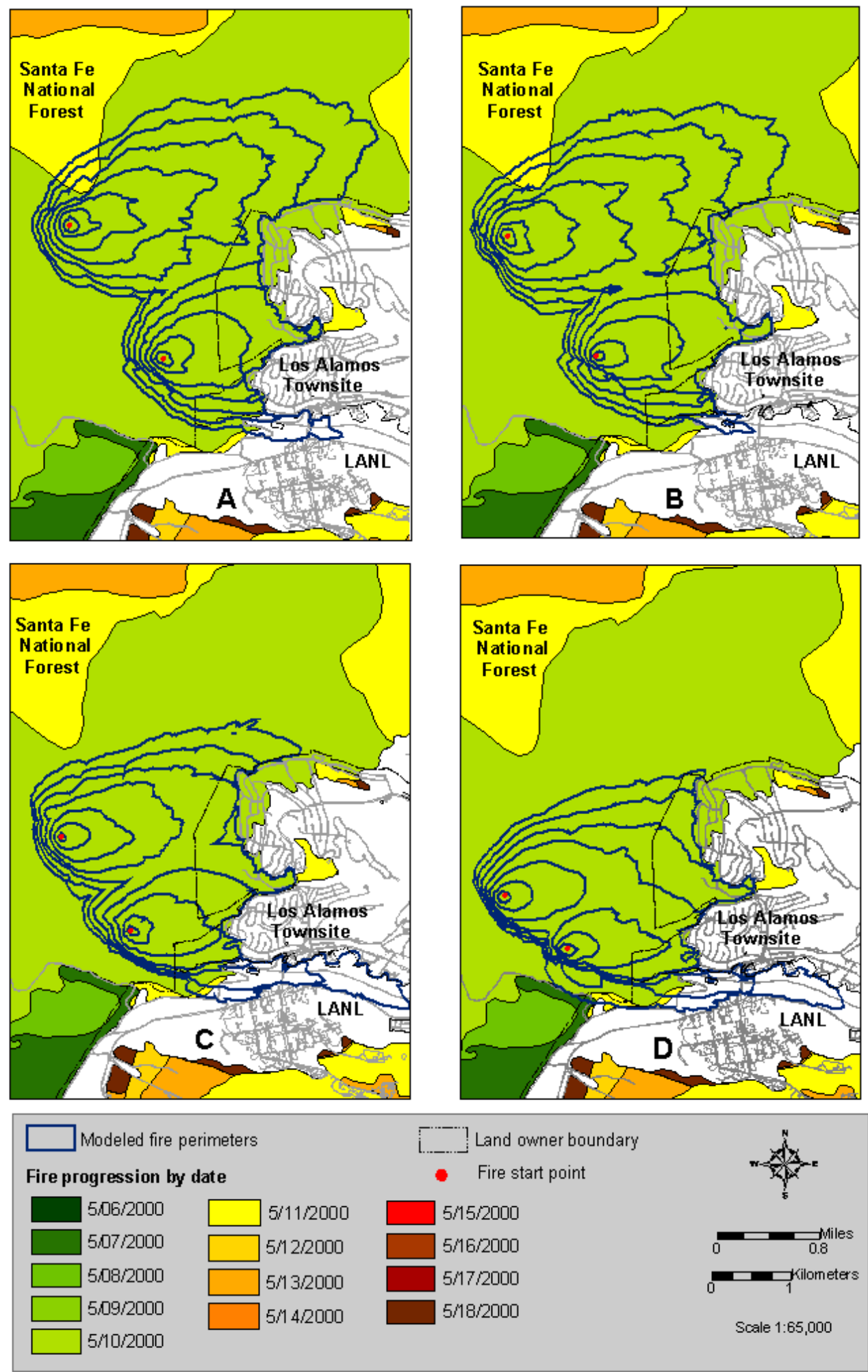

Figure 8. Model results at two-hour intervals of the Wednesday, May 10, northern segment of the Cerro Grande Fire using weather data from Pajarito Mountain. (Note: LANL indicates Los Alamos National Laboratory.) 


\section{Cerro Grande Fire South; May 10, 2000}

The southern segment of the Cerro Grande Fire that burned on LANL property on Wednesday, May 10, 2000, was also used to validate the modeling system. In a manner similar to the northern segment of the Cerro Grande Fire, the southern segment had been burning without major advancements for two days. By Tuesday night, May 9, the fire was continuing to burn to the west of State Highway 501 and had not entered onto LANL property that is to the east of this highway (Figure 9). However, the Cerro Grande Fire on LANL was initiated on the morning of May 10 when burning embers were transported to the east across the highway by winds. The exact locations of the landing points for these embers have not been determined. However, the general agreement among fire fighters who were assigned to this segment of the Cerro Grande Fire is that one of the starting points for the fire was in the central, or southwestern portions of TA-16 (ESA) in the vicinity of Water Canyon or to the north of Water Canyon. Additional fire starting locations have been attributed to various locations from TA-16 to TA-9, or in areas to the north and east of these TAs.

For the purposes of this validation exercise, several model runs were completed under constant conditions except for the locations of the starting points of the fires. Two or three starting points were used and their locations were varied to determine the best method for modeling the actual fire. As before, a 15-hour fire, from 9 AM to midnight, was modeled. Weather data from the TA-49 weather tower were used. The actual fire progression and perimeter polygons used to validate the model outputs were adopted from the fire progression map developed by the Incident Command Team (Cerro Grande Fire, Incident Command 2000).

Four of the modeled fires were selected and reproduced in Figure 9. All four of these candidate model outputs appeared to model the advancing front of fire with reasonable fidelity. However, all four of the candidate runs overpredicted the spread of the Cerro Grande Fire to the south and the southeast of the actual fire, and two of these model outputs (Figure 9C and 9D) exhibited extensive overprediction to the south and the southeast.

These results corroborate results from previous validation exercises for the TA-40 fire and the Cerro Grande Fire. They emphasize the importance of obtaining local weather data, and the establishment of correct locations for the ignition of fires. The results for the southern segment of the Cerro Grande Fire also demonstrate the need for accurate identification of fuels and for the correct internal rate of fire spreads that are assigned to these fuels. For example, noting that the model outputs in Figure 9 overpredict to the south and the southeast, we can also note that this area was burned in the La Mesa Fire and was vegetated by grassland and shrublands in 2000. This suggests that the internal settings for fire rate of spread for these fuel types (fuel models 1 and 2) may be too liberal when compared to fuel models for ponderosa pine forest (fuel model 9).

\section{Operations Application}

The wildfire behavior modeling system was recently installed in a computer at the LANL Emergency Operations Center, where it is available to model the progress of currently burning fires to meet the needs of operational and emergency activities (Balice and Koch 2002). The modeling system has also found application to evaluations of current landscape conditions and the fire behaviors that these landscapes may be expected to support. 

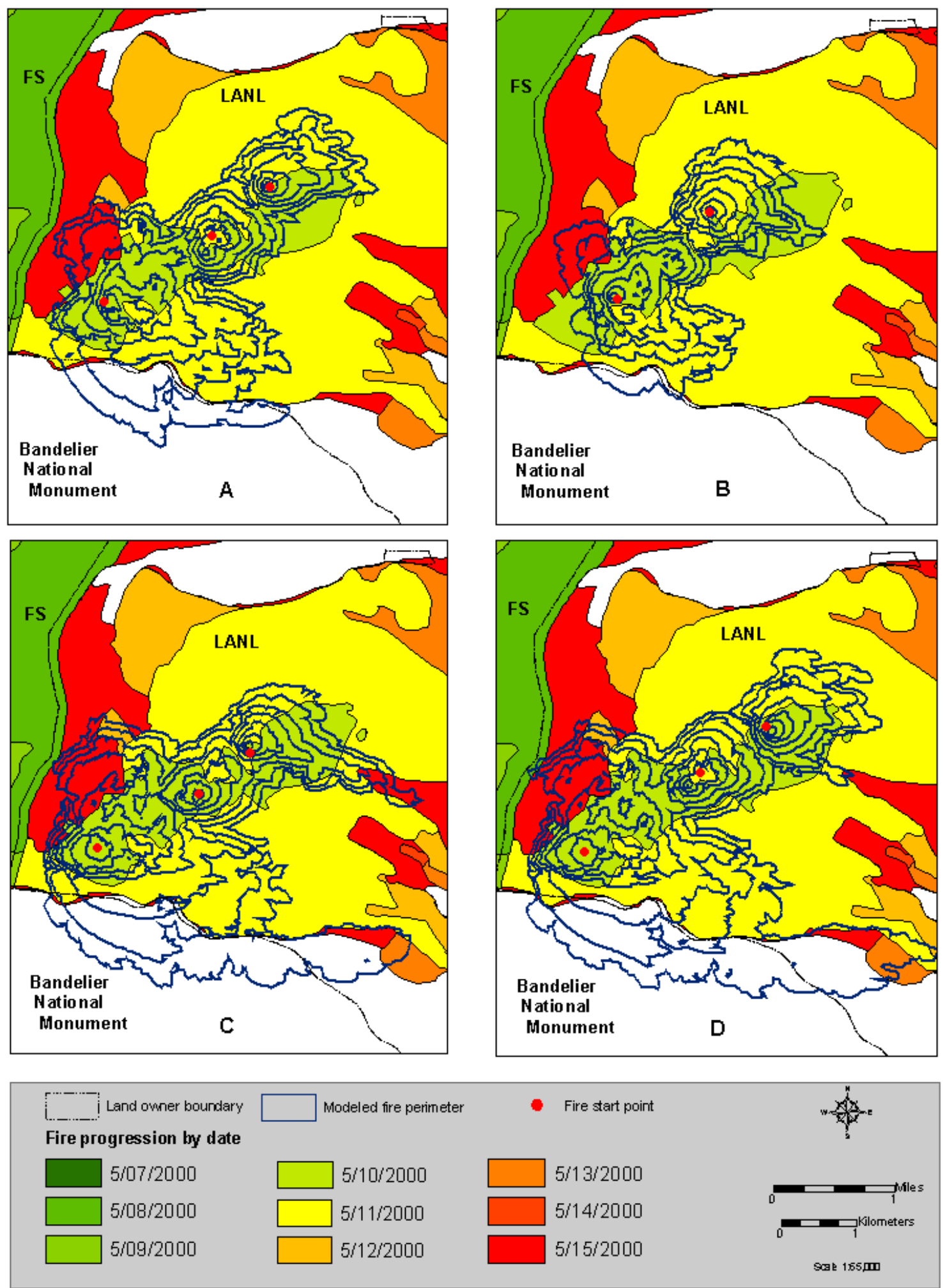

Figure 9. Model results at two-hour intervals of the Wednesday, May 10, southern segment of the Cerro Grande Fire using weather data from TA-49. (Note: FS and LANL indicate Forest Service and Los Alamos National Laboratory, respectively.) 
As an example of an operational application, we recently evaluated the potential fire behavior, under post-Cerro Grande Fire conditions, in the area surrounding the southwestern portion of LANL. To accomplish this, we selected one of the lightning strikes, number 1002, from the lightning-strike database, and assumed that it would initiate a wildland fire at its location, which is in upper Frijoles Canyon near State Highway 4. Next we used the post-Cerro Grande Fire data layers and assumed that areas that were severely burned during the Cerro Grande Fire were unable to support a second fire. This would be typical of fuel conditions that existed during the 2000 and 2001 fire seasons. We also used the weather conditions that were present during the Cerro Grande Fire. Weather data from the Pajarito weather tower and the TA-49 weather tower were both used as inputs according to which was closer to the advancing front of the simulated fire. Under these conditions, we modeled the progress of the fire, without suppression, for two three-day periods. The first period was from May 7, 2000, to May 9, 2000 (Figure 10). The second three-day period was from May 9, 2000, to May 11, 2000 (Figure 11).

The results of these two modeling scenarios were informative (Figures 10 and 11). In both cases, the growth of the modeled fire was slowed considerably during the first day by the presence of previously burned and largely unburnable lands to the east of the fire initiation point. However, the modeled wildfires increased dramatically in size during the second day as they encroached on heavily fueled landscapes to the south of the Cerro Grande Fire burned area and proceeded eastward with the prevailing winds. In both of these cases, the fire entered onto LANL property during the second day. In the first scenario, the third day of burning engulfed much of the western and southern portions of LANL (Figure 10). In the second scenario, the fire had burned over much of the western and southern portions of LANL, but also continued in a significant run to the northeast (Figure 11). In particular, the modeled fire in the second scenario crossed Pajarito Road and continued to the intersection of East Jemez Road and State Highway 4 by the end of the third day.

A second operational application of this fire behavior modeling system was conducted in the eastern portions of LANL where fires can begin in canyons and spread to the adjacent mesas. The area of lower Pajarito Canyon that includes TA-36 and TA-54 was selected for this exercise. To investigate the potential fire behaviors in this area, we initiated fires along Pajarito Road and simulated these fires for four hours, from 9 AM to 1 PM. The weather conditions were those experienced during the Cerro Grande Fire on May 7 and May 10, 2000.

The results of these simulations suggest that wildfires can burn extensively within a four-hour time period (Figure 12). Moreover, the residents of TA-54 would have only two hours to evacuate the area before the advancing flames begin to overtake the mesa.

\section{Discussion}

The general applicability to wildfire management and emergency operations of this approach to modeling fire behaviors, based on the acquisition of extensive field data and timely weather data for use as inputs to previously validated modeling software, has been demonstrated and discussed elsewhere (Balice, Oswald, and Martin 1999; Balice, Oswald, and Yool 2000; Keane et al. 2000; Yool et al. 2000; Bare et al. 2001; Schmidt et al. 2002; Webb and Balice 2004). As one example, wildfire hazard data collected in the field are useful for assessing wildfire hazard 
- Lightning strike 1002 Owner boundary

Paved road

TA boundary

Sunday, May 7, 2000

Monday, May 8, 2000

Tuesday, May 9, 2000

Cerro Grande burn severity

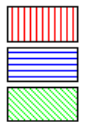

High

Mod

Low/Unb
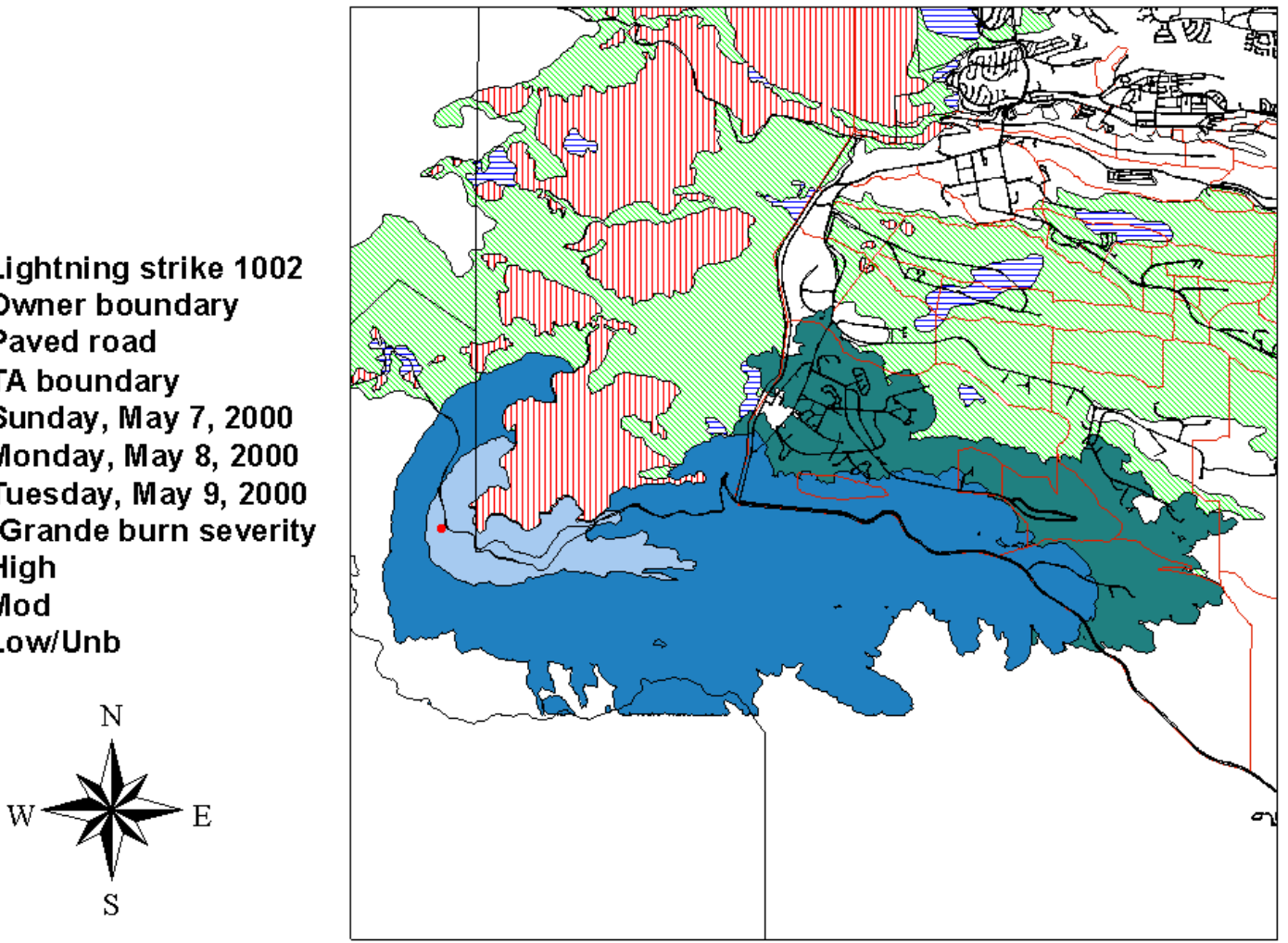

Figure 10. Results of a simulated three-day wildfire, using conditions from 5/7/00 to 5/9/00.
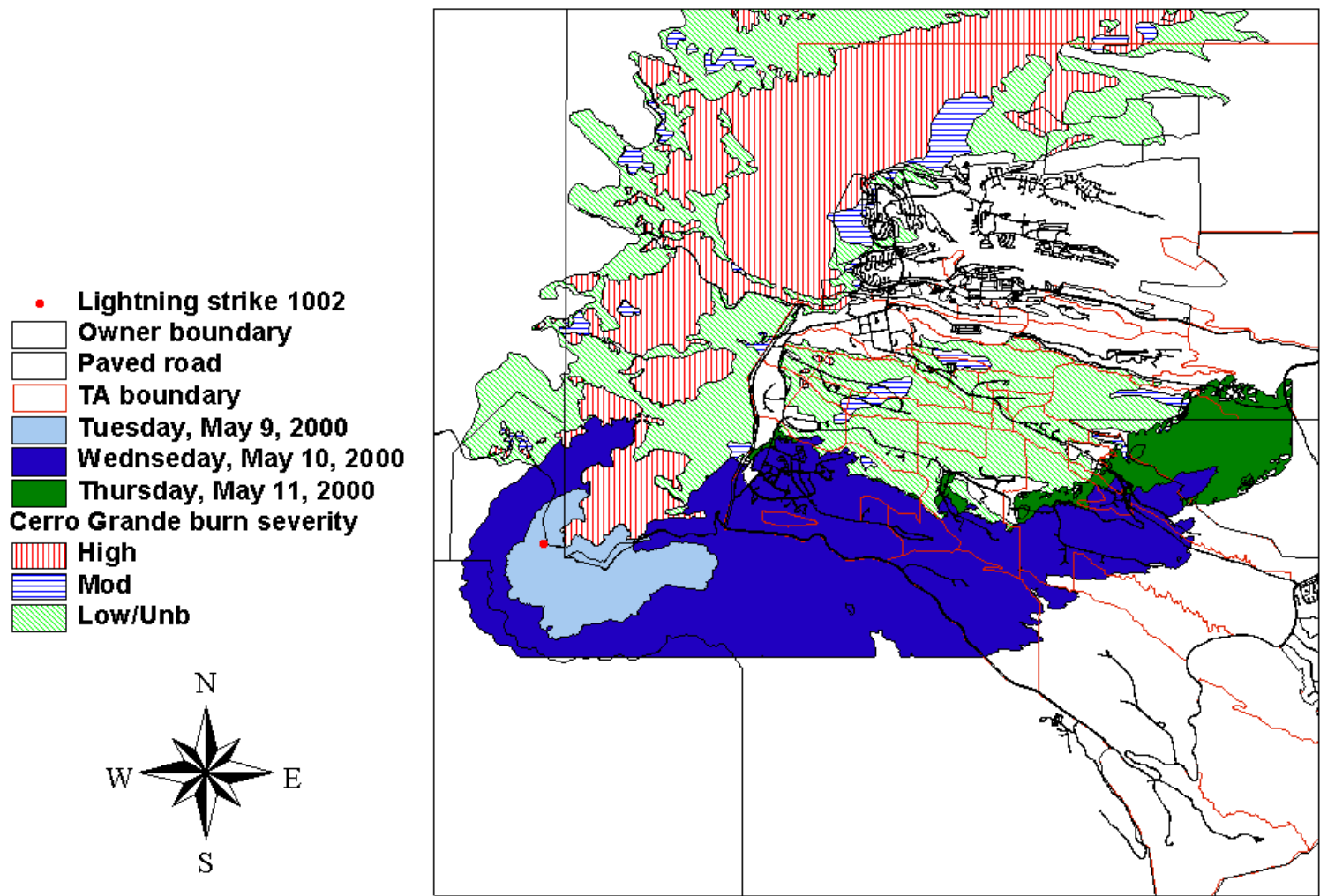

Figure 11. Results of a simulated three-day wildfire, using conditions from 5/9/00 to 5/11/00. 

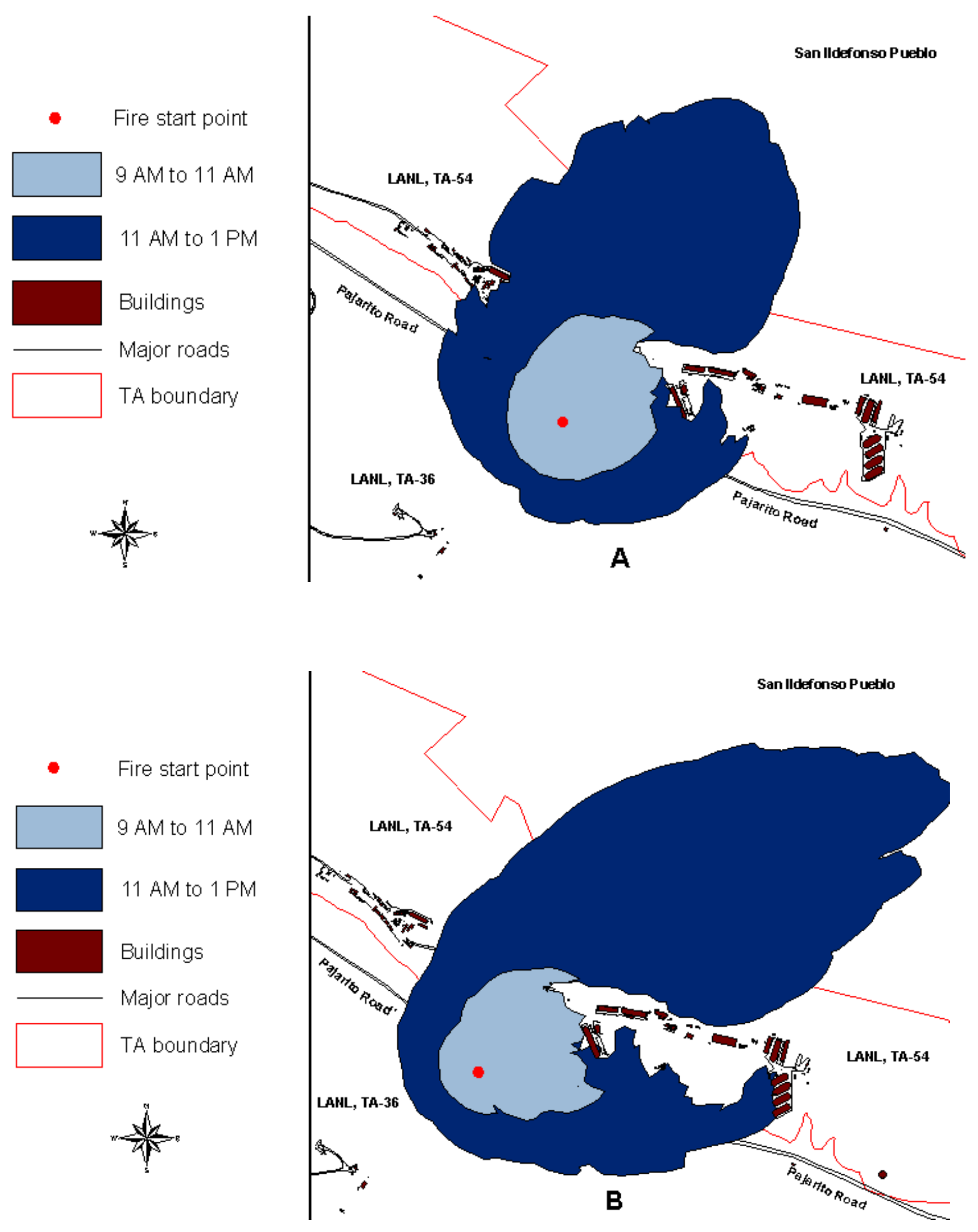

Figure 12. Results of a simulated four-hour wildfire in the TA-36 and TA-54 areas of Los Alamos National Laboratory, using conditions from (A) 5/7/00 and (B) 5/10/00. 
levels before and after the application of mitigation treatments and to evaluate the progress of wildfire hazard reduction programs (Balice 2001, 2002). In another example, an updated version of the post-Cerro Grande Fire wildfire behavior modeling system that was installed for emergency management purposes at the Emergency Operations Center at LANL during 2002 has been useful for the assessment of operational fires during emergency situations (Balice and Koch 2002).

The consequences of the Cerro Grande Fire emphasize that the environmental models and their supporting databases, such as the wildfire modeling system described in this report, are frequently outdated by acts of nature. In addition to the effects of wildfire, the tree mortality events of 2002 and 2003, which were extensive in the piñon-juniper woodlands of the Los Alamos region, also point to the inevitability of change in our environmental surroundings and the need for frequent updates of the databases that are used as inputs to environmental modeling systems (Balice, Anderson, and Cobb 2003; Balice et al. 2003; Kuenzi, Balice, and Trader 2003). Moreover, changes in land-use and wildfire hazard reduction activities are examples of humancaused change that can also be significant. As a result of these inevitable and extensive changes to our environments, the databases for the wildfire behavior modeling system require frequent updates, even annual updates, to maintain a high level of reliability in the model outputs and results. The proactive collection of field data on a regular basis followed by frequent updates and validation of the input databases has the additional advantage that reliable model outputs can be produced quickly as desired by various land managers and emergency personnel to evaluate operational fires or for other purposes that require a quick response.

As a product of a Federal agency, FARSITE is readily available to the user at no cost. However, the success of the resulting modeling system is entirely dependent on the availability of highly reliable and accurate data that reflect local conditions. The initial validation successes that were described in this report are directly attributable to the high-quality fuels, topography, and weather data that were used as inputs. The cost of acquiring new data to update the model is more than returned by the enhancements to the capabilities of the modeling system. For instance, with these new and current data from field monitoring, it is possible to develop locally relevant data structures, such as custom fuel models (Balice and Breshears 2003). Locally relevant data generated during field monitoring were also used to produce parameter values that are difficult and expensive to obtain by applying previously developed allometric relationships (Meeuwig 1979, Reinhardt 2001). In addition, the costs of fieldwork are alleviated by incorporating the goals of several projects into a single, comprehensive data collection activity. The recently completed land cover map for the eastern Jemez Mountains is one example where costs were minimized by adopting field data for multiple applications (McKown et al. 2003).

The results of this project demonstrate that FARSITE may be used in combination with other models to produce a wide range of results that are of management importance. Many of these software applications are available at no cost to the user. For instance, forest growth and yield models are useful for projecting fuels conditions into the future or the past (Wyckoff, Crookston, and Stage 1982; Dixon 2000, 2002; Reinhardt and Crookston 2003). In addition to modeling future wildfire scenarios, forest growth and yield models have application to revision of management plans (Rupe and Wisler 1997). Other complementary modeling tools can produce outputs of wildfire behaviors at individual locations and under specific conditions (Andrews 
1986); create raster maps of potential fire characteristics across landscapes (Finney, Britten, and Seli 2003); simulate long-term forest dynamics under various fire regimes (Keane, Morgan, and Running 1996); predict tree mortality, fuel consumption, smoke production, and soil heating caused by prescribed fire or wildfire (Reinhardt, Keane and Brown 1997); and link predictions from surface fire models and crown fire models (Scott 1999, Scott and Reinhardt 2001).

Finally, it is important to note that specific outputs from fully parameterized modeling software, such as FARSITE, constitute only one possible scenario for a given event. The model may be conservative with regard to one aspect of the output and may be liberal with regard to a different aspect of the output. To achieve the full potential of the model capabilities, the output of potentially variable results that may not correspond fully with reality must be recognized and interpreted by fire behavior experts. Consequently, the model outputs do not replace the expertise of professionals in the wildfire and land management disciplines. In contrast, modeling results are merely tools that should be utilized by a team of experts, in combination with results from other available models and tools, to arrive at informed conclusions and decisions with regard to the modeled phenomenon.

\section{Acknowledgments}

We gratefully acknowledge the former LANL Environment, Safety and Health Division's Technology Development, Evaluation and Assessment Program for providing research funding for the development and testing of the wildfire behavior modeling system. We also wish to thank the US Department of Agriculture Forest Service Rocky Mountain Experiment Station and the Ecology Group's Biological Resources Management Program at LANL for providing additional funds for the collection of field monitoring data at permanent plots in forests and woodlands of the Los Alamos region. LANL's Cerro Grande Rehabilitation Project also supported this project during the development of updates of the modeling system after the Cerro Grande Fire.

Many people contributed to the success of this project and are gratefully acknowledged. Dave Smith and Abram Jacobsen (Space and Atmospheric Sciences Group, LANL) made the lightning data available for use by this project. Steve Booth (Energy and Environmental Analysis, LANL) shared information of economic data and approaches to economic analyses related to fire hazard modeling at LANL. Sandra White assisted with the wildfire simulations that were used to perform the economic analyses and for other purposes. Marjorie Wright performed some of the GIS analyses and produced many of the maps for this document. Hector Hinojosa assisted with the security reviews at LANL and contributed to the production of the final report. Hector Hinojosa, Sam Loftin, and Leonard Sandoval conducted critical reviews of earlier drafts of this report. 


\section{Literature Cited}

Abraham, S. 2003. Department of Energy (DOE) Wildland Fire Management Policy. Memorandum (2002-019296) from the Secretary of Energy for the Deputy Secretary, Undersecretary for Energy, Science and the Environment, and the Administrator of the National Nuclear Security Administration. US Department of Energy, Washington, D.C.

Air Quality Group. 2001. The LANL weather machine: raw data request form. Web page (http://weather.lanl.gov/cgi-bin/datarequest) maintained by the Air Quality Group (RRESMAQ), Los Alamos National Laboratory, Los Alamos, New Mexico.

Anderson, H.E. 1982. Aids to determining fuel models for estimating fire behavior. General Technical Report INT-122, US Department of Agriculture, Forest Service, Intermountain Forest and Range Experiment Station, Ogden, Utah.

Andrews, P.L. 1986. BEHAVE: Fire and behavior prediction and fuel modeling system BURN subsystems, Part 1. General Technical Report INT-194, US Department of Agriculture, Forest Service, Intermountain Forest and Range Experiment Station, Ogden, Utah.

Baars, J., D. Holt, and G. Stone. 1998. Meteorological monitoring at Los Alamos. LA-UR-982148, Los Alamos National Laboratory, Los Alamos, New Mexico.

BAER Team. 2000. Cerro Grande Fire burned area emergency rehabilitation (BAER) plan. Prepared by the Interagency BAER Team, Los Alamos, New Mexico.

Balice, R.G. 1998. A preliminary survey of terrestrial plant communities in the Sierra de los Valles. LA-13523-MS, Los Alamos National Laboratory, Los Alamos, New Mexico.

Balice, R.G. 2001. Pre-mitigation and post-mitigation monitoring: Report for the end of the 2001 field season. Report submitted to the Cerro Grande Rehabilitation Project Office (October 31, 2001) by the Ecology Group, Los Alamos National Laboratory, Los Alamos, New Mexico.

Balice, R.G. 2002. Demonstration of selected wildfire hazard reduction treatments: Pretreatment data report. Report submitted to the Cerro Grande Rehabilitation Project Office (July 29, 2002) by the Ecology Group, Los Alamos National Laboratory, Los Alamos, New Mexico.

Balice, R.G. and D.D. Breshears. 2003. Fuel structure and fire behavior in pinyon-juniper woodlands: Contrasting low vs. high density understory scenarios. Presented at the Eightyeighth Annual Meeting of the Ecological Society of America (August 3-8, 2003), Savannah, Georgia. 
Balice, R.G. and S.W. Koch. 2001. Regression modeling to enhance spatial representations of fuel loads and fire hazards. LA-UR-01-1090. Poster presented at the Environment, Safety and Health Division Review Committee Meeting, Los Alamos National Laboratory (March 13-15, 2001), Los Alamos, New Mexico.

Balice, R.G. and S.W. Koch. 2002. EOC implementation of the RRES-ECO Wildfire Behavior Modeling System: Final report. Submitted to the Cerro Grande Rehabilitation Project Office. LA-UR-02-3682, Los Alamos National Laboratory, Los Alamos, New Mexico.

Balice, R.G., S.G. Ferran, and T.S. Foxx. 1997. Preliminary vegetation and land cover classification for the Los Alamos region. LA-UR-97-4627, Los Alamos National Laboratory, Los Alamos, New Mexico.

Balice, R.G., B.P. Oswald, and C. Martin. 1999. Fuels inventories in the Los Alamos National Laboratory region: 1997. LA-13572-MS, Los Alamos National Laboratory, Los Alamos, New Mexico.

Balice, R.G., B.P. Oswald, and S.R. Yool. 2000. Fuels inventories and spatial modeling of fire hazards in the Los Alamos region. Pages 138-147 in Proceedings of the Crossing the Millennium: Integrating Spatial Technologies and Ecological Principles for a New Age in Fire Management Conference and Workshop, Volume I (Technical Editors: L.F.

Neuenschwander and K.C. Ryan). University of Idaho and International Association of Wildland Fire, Moscow, Idaho.

Balice, R.G., J. Anderson, and N.S. Cobb. 2003. Drought thresholds that induce bark-beetle mortality in Colorado pinyon (Pinus edulis). LA-UR-03-7032. Presented at the $7^{\text {th }}$ Biennial Conference on Integrating Science and Management on the Colorado Plateau (November 6, 2003), Flagstaff, Arizona.

Balice, R.G., A. Kuenzi, T. Edelen, and L. Trader. 2003. Relationships between recent weather trends and tree mortality in northern New Mexico. LA-UR-03-1337. Presented at the Seventh Symposium of Biological Research in the Jemez Mountains, New Mexico (February 27, 2003), Santa Fe, New Mexico.

Balice, R.G., S.W. Koch, P. Valerio, S. Loftin, and J. Baars. 1998. A wildfire behavior model for the Los Alamos region and an evaluation of options for mitigating fire hazards. Proposal to the Environment, Safety and Health Division Technology Development, Evaluation, and Application Program. Ecology Group, Los Alamos National Laboratory, Los Alamos, New Mexico.

Balice, R.G., J.D. Miller, B.P. Oswald, C. Edminster, and S.R. Yool. 2000a. Forest surveys and wildfire assessment in the Los Alamos region; 1998-1999. LA-13714-MS, Los Alamos National Laboratory, Los Alamos, New Mexico.

Balice, R.G., S.W. Koch, P. Valerio, S. Loftin and J. Baars. 2000b. A wildfire behavior model for the Los Alamos Region and an evaluation of options for mitigating fire hazards. Pages 
4-7 in Technology Development,Evaluation and Assessment (TDEA) FY1999 Progress Report. LA-13766-PR, Environment, Safety and Health Division, Los Alamos National Laboratory, Los Alamos, New Mexico.

Balice, R.G., S.W. Koch, J.W. Nyhan, S. Loftin, P. Valerio, and G. Fenton. 2002a. A wildfire behavior model for the Los Alamos region and an evaluation of options for mitigating fire hazards. Pages 4-9 in Technology Development, Evaluation and Assessment (TDEA) FY 2001 Progress Report. LA-13924-PR, Environment, Safety and Health Division, Los Alamos National Laboratory, Los Alamos, New Mexico.

Balice, R.G., S.W. Koch, S. Loftin, J.W. Nyhan, P. Valerio, and G. Fenton. 2002b. A wildfire behavior model for the Los Alamos region and an evaluation of options for mitigating fire hazards. Pages 4-7 in Technology Development, Evaluation and Assessment (TDEA) FY 2000 Progress Report. LA-13901-PR, Environment, Safety and Health Division, Los Alamos National Laboratory, Los Alamos, New Mexico.

Bare, C.M., R.G. Balice, L.A. Hansen, S. Loftin, M. Wright, and P. Valerio. 2001. Wildfire hazard reduction project plan. LA-UR-01-2017, Los Alamos National Laboratory, Los Alamos, New Mexico.

Bennett, K., S.W. Koch, S. Gebhardt, M. Wright, and W. Red Star. 2001. GIS applications within the Ecology Group of LANL. LA-UR-01-1209, Los Alamos National Laboratory, Los Alamos, New Mexico.

Brown, J.K. 1974. Handbook for inventorying downed woody material. General Technical Report INT-16, US Department of Agriculture, Forest Service, Intermountain Forest and Range Experiment Station, Ogden, Utah.

Brown, J.K., R.D. Oberheu, and C.M. Johnston. 1982. Handbook for inventorying surface fuels and biomass in the interior west. General Technical Report INT-129, US Department of Agriculture, Forest Service, Intermountain Forest and Range Experiment Station, Ogden, Utah.

Cerro Grande Fire, Incident Command. 2000. Cerro Grande Fire (NM-SNF-043), Fire Behavior and Weather Documentation CD (March 6-24, 2000). Compiled by Kelly Close, Poudre Fire Authority, Fort Collins, Colorado.

Davis, J.C. 1973. Statistics and data analysis in geology, second edition. John Wiley \& Sons, Inc., New York, New York.

DeVelice, R.L., J.A. Ludwig, W.H. Moir, and F. Ronco, Jr. 1986. A classification of forest habitat types of northern New Mexico and southern Colorado. General Technical Report RM-131, US Department of Agriculture, Forests Service, Rocky Mountain Forest and Range Experiment Station, Fort Collins, Colorado. 
Dixon, G.E. 2000. Central Rockies variant of the Forest Vegetation Simulator. US Department of Agriculture, Forest Service, Forest Management Service Center, Fort Collins, Colorado.

Dixon, G.E. 2002. Essential FVS: A user's guide to the Forest Vegetation Simulator. US Department of Agriculture, Forest Service, Forest Management Service Center, Fort Collins, Colorado.

DOE. 2003. Environmental Protection Program. Order DOE O 450.1, US Department of Energy, Washington, D.C.

DOE LAAO. 2000. Environmental Assessment for the Wildfire Hazard Reduction and Forest Health Improvement Program at Los Alamos National Laboratory, Los Alamos, New Mexico. DOE-EA-1329, prepared by US Department of Energy, Los Alamos Area Office, Los Alamos, New Mexico.

ESRI. 2003. ArcGIS, version 8.3. Environmental Systems Research Institute (ESRI), Redlands, California.

Finney, M.A. 1998. FARSITE: Fire area simulator-model development and evaluation. Research Paper RMRS-RP-4, US Department of Agriculture, Forest Service, Rocky Mountain Research Station, Fort Collins, Colorado.

Finney, M.A., S. Britten, and R. Seli. 2003. FlamMap, Beta version. US Department of Agriculture, Forest Service, Fire Science Laboratory, Missoula, Montana.

Jacobson, A.R., K.L. Cummins, M. Carter, P. Klingner, D. Roussel-Dupré, and S. O. Knox. 2000. FORTE radio-frequency observations of lightning strokes detected by the National Lightning Detection Network. Journal of Geophysical Research 105 (D12), 15,653-15,662.

Keane, R.E., P. Morgan, and S.W. Running. 1996. FIRE-BGC - A mechanistic ecological process model for simulating fire succession on coniferous forest landscapes of the northern Rocky Mountains. Research Paper, INT-RP-484, US Department of Agriculture, Forest Service, Rocky Mountain Research Station, Ogden, Utah.

Keane, R.E., J.L. Garner, K.M. Schmidt, D.G. Long, J.P. Menakis, and M.A. Finney. 1998. Development of input data layers for FARSITE fire growth model for the Selway-Bitterroot Wilderness Complex, USA. General Technical Report RMRS-GTR-3, US Department of Agriculture, Forest Service, Rocky Mountain Research Station, Ogden, Utah.

Keane, R.E., S.A. Mincemoyer, K.M. Schmidt, D.G. Long, and J.L. Garner. 2000. Mapping vegetation and fuels for fire management on the Gila National Forest Complex, New Mexico. General Technical Report RMRS-GTR-46-CD, US Department of Agriculture, Forest Service, Rocky Mountain Research Station, Ogden, Utah. 
Koch, S.W. and R.G. Balice. 1999. Input data development for the FARSITE fire area simulator for the Los Alamos National Laboratory region. LA-UR-99-3818. Poster presented at the ESRI User Conference (June 26, 1999), San Diego, California.

Koch, S.W., T.K. Budge, and R.G. Balice. 1997. Development of a land cover map for Los Alamos National Lab and vicinity. LA-UR-97-4628, Los Alamos National Laboratory, Los Alamos, New Mexico.

Koch, S.W, R.G. Balice, J.W. Nyhan, and S.R. Loftin. 2000. Validation and sensitivity analyses of a wildfire behavior model. LA-UR-00-1786, poster presented at the Environment, Safety, and Health Division Review, Los Alamos National Laboratory (April 11-13, 2000), Los Alamos, New Mexico.

Komarkova, V., R.R. Alexander, and B.C. Johnston. 1988. Forest vegetation of the Gunnison and parts of the Uncomphagre National Forests: A preliminary habitat type classification. General Technical Report RM-163, US Department of Agriculture, Forest Service, Rocky Mountain Forest and Range Experiment Station, Fort Collins, Colorado.

Kuenzi, A., R.G. Balice, and L. Trader. 2003. Effects of drought and insect infestation on ponderosa pine forests and pinyon and juniper woodlands in Bandelier National Monument and Los Alamos National Laboratory, New Mexico. Poster presented at the 2003 National Fire Plan Conference (January 13-15, 2003), New Orleans, Louisiana.

McKown, B., S.W. Koch, R.G. Balice, and P. Neville. 2003. Land cover classification map for the Eastern Jemez Region. LA-14029, Los Alamos National Laboratory, Los Alamos, New Mexico.

Miller, J.D., J.W. Nyhan, and S.R. Yool. 2003. Modeling potential erosion due to the Cerro Grande Fire with a GIS-based implementation of the Revised Universal Soil Loss Equation. International Journal of Wildland Fire 12:85-100.

Mueggler, W.F. 1988. Aspen community types of the Intermountain Region. General Technical Report INT-250, US Department of Agriculture, Forests Service, Intermountain Research Station, Ogden, Utah.

Mueggler, W.F. and R.B. Campbell, Jr. 1986. Aspen community types of Utah. Research Paper INT-362, US Department of Agriculture, Forests Service, Intermountain Research Station, Ogden, Utah.

Meeuwig, R.O. 1979. Growth characteristics of pinyon-juniper stands in the western Great Basin. Research Paper INT-238, US Department of Agriculture, Forest Service, Intermountain Forest and Range Experiment Station, Ogden, Utah.

Nyhan, J.W. and L.J. Lane. 1986. Erosion control technology: A user's guide to the use of the Universal Soil Loss Equation at waste burial facilities. LA-10262-M, Los Alamos National Laboratory, Los Alamos, New Mexico. 
Nyhan, J.W., L.W. Hacker, T.E. Calhoun, and D.L. Young. 1978. Soil survey of Los Alamos County, New Mexico. LA-6779-MS, Los Alamos National Laboratory, Los Alamos, New Mexico.

Pfister, R.D., B.L. Kovalchik, S.F. Arno, and R.C. Presby. 1977. Forest habitat types of Montana. General Technical Report INT-34, US Department of Agriculture, Forest Service, Intermountain Forest and Range Experiment Station, Ogden, Utah.

Reinhardt, E.D. 2001. Spreadsheet forest canopy fuels calculator for the northern Rocky Mountains. US Department of Agriculture, Forest Service, Fire Sciences Laboratory, Missoula, Montana.

Reinhardt, E.D. and N.L. Crookston (Technical editors). 2003. The fire and fuels extension to the forest vegetation simulator. General Technical Report RMRS-GTR-116, US Department of Agriculture, Forest Service, Rocky Mountain Research Station, Ogden, Utah.

Reinhardt, E.D., R.E. Keane, and J.K. Brown. 1997. First-order fire effects model: FOFEM 4.0, User's Guide. General Technical Report INT-GTR-344, US Department of Agriculture, Forest Service, Intermountain Research Station, Ogden, Utah.

Rothermal, R.C. 1983. How to predict the spread and intensity of forest and range fires. General Technical Report INT-143, US Department of Agriculture, Forest Service, Intermountain Forest and Range Experiment Station, Ogden, Utah.

Rupe, J.B. and W.R. Wisler. 1997. Use of FVS in the Black Hills National Forest Plan revision. Pages 75-78 in Proceedings: Forest Vegetation Simulator Conference (Compilers: R. Teck, M. Moeur, J. Adams). General Technical Report INT-GTR-373, US Department of Agriculture, Forest Service, Rocky Mountain Research Station, Ogden, Utah.

Schmidt, K.M., J.P. Menakis, C.C. Hardy, W.J. Hann, and D.L. Bunnell. 2002. Development of coarse-scale spatial data for wildland fire and fuel management. General Technical Report RMRS-87, US Department of Agriculture, Forest Service, Rocky Mountain Research Station, Fort Collins, Colorado.

Scott, J.H. and E.D. Reinhardt. 2001. Assessing crown fire potential by linking models of surface and crown fire behavior. Research Paper RMRS-RP-29, US Department of Agriculture, Forest Service, Rocky Mountain Research Station, Fort Collins, Colorado.

Scott, J.H. 1999. NEXUS: A system for assessing crown fire hazard. Fire Management Notes 59(2):20-24.

Site-wide Issues Program Office. 2000. A special edition of the SWEIS yearbook: Wildfire 2000. LA-UR-00-3471, Los Alamos National Laboratory, Los Alamos, New Mexico. 
Smith, D.A., K.B. Eack, J. Harlin, M.J. Heavner, A.R. Jacobson, R.S. Massey, X.M. Shao and K.C. Wiens. 2002. The Los Alamos Sferic Array: A research tool for lightning investigations. Journal of Geophysical Research 107(D13), ACL 5-1-ACL 5-14.

USGS. 2001. National elevation dataset. Website (http://edcnts12.cr.usgs.gov/ned/About.htm) maintained by the United States Geological Survey (USGS), Renton, Virginia.

Webb, M.D. and R.G. Balice. 2004. A real-time wildfire model for Los Alamos, New Mexico. International Journal of Technology Transfer and Commercialisation 3(2):226-242.

Wischmeier, W.H. and D.D. Smith. 1978. Predicting rainfall erosion losses - a guide to conservation planning. US Department of Agriculture, Handbook 537, US Government Printing Office, Washington, D.C.

Wyckoff, W.R., N.L. Crookston, and A.R. Stage. 1982. User's guide to the Stand Prognosis Model. General Technical Report INT-133, US Department of Agriculture, Forest Service, Intermountain Forest and Range Experiment Station, Ogden, Utah.

Yool, S.R., J.D. Miller, R.G. Balice, B.P. Oswald, and C. Edminster. 2000. Mapping fuel risk at the Los Alamos urban-wildland interface. Pages 228-234 in Proceedings of the Crossing the Millennium: Integrating Spatial Technologies and Ecological Principles for a New Age in Fire Management Conference and Workshop, Volume I (Technical Editors: L.F. Neuenschwander and K.C. Ryan). University of Idaho and International Association of Wildland Fire, Moscow, Idaho. 
This report has been reproduced directly from the best available copy. It is available electronically on the Web (http://www.doe.gov/bridge).

Copies are available for sale to U.S. Department of Energy employees and contractors from:

Office of Scientific and Technical Information P.O. Box 62

Oak Ridge, TN 37831

(865) 576-8401

Copies are available for sale to the public from: National Technical Information Service

U.S. Department of Commerce

5285 Port Royal Road

Springfield, VA 22161

(800) 553-6847 


$$
\text { EST.1943 }
$$

